2. To: (Receiving Organization)

Distribution

5. Proj./Prog./Dept./Div.:

Spent Nuclear Fuel Project

8. Originator Remsrks:

Approval and Release.

11. Receiver Remarks: 11A. Design Baseline Document? [] Yes [X] No
3. From: (Originating Organization) Spent Nuclear Fuel

Evaluations

6. Design Authority/ Design Agent/Cog. Engr.:

A. L. Pitner
4. Related EDT No.:

$N / A$

7. Purchase Order No.:

$N / A$

9. Equip./Component No.: $N / A$

10. System/Bldg./Facility: $N / A$

12. Major Assm. Dwg. No.: $N / A$

13. Permit/Permit Application No.: $N / A$

14. Required Response Date: $N / A$

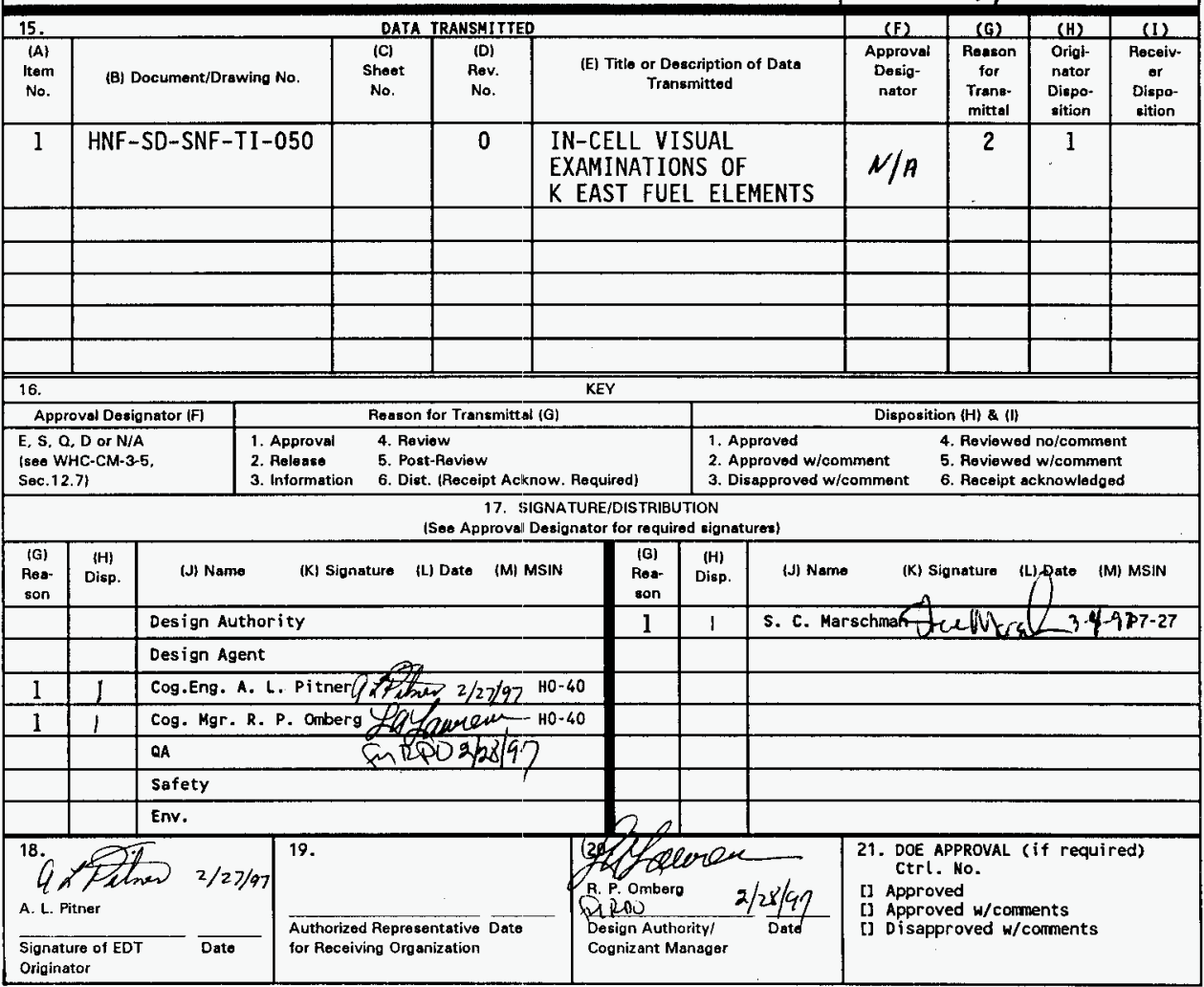




\section{IN-CELL VISUAL EXAMINATIONS OF K EAST FUEL ELEMENTS}

A. L. Pitner

Duke Engineering \& Services Hanford, Inc., Richland, WA 99352

U.S. Department of Energy Contract DE-AC06-96RL13200

T. D. Pyecha

Pacific Northwest National Laboratory, Richland, WA 99352

U.S. Department of Energy Contract DE-AC06-76RL0-1830

$\begin{array}{lll}\text { EDT/ECN: } & 620781 & \text { UC: } 2070 \\ \text { Org Code: } & 2 T 650 & \text { Charge Code: } \\ \text { B\&R Code: } & \text { EW707027 }\end{array}$

Key Words: K Basin, Fuel Examinations, Fuel Damage

Abstract: Nine outer fuel elements were recovered from the $K$ East Basin and transferred to a hot cell for examination. Extensive testing planned for these elements will support the process design for the Integrated Process Strategy (IPS), with emphasis on drying and conditioning behavior. Visual examinations of the fuel elements confirmed that they are appropriate to meet testing objectives to provide design guidance for IPS processing parameters.

TRADEMARK DISCLAIMER. Reference herein to any specific commercial product, process, or service by trade name, tradenark, manufacturer, or otherwise, does not necessarily constitute or imply its endorsement, recomendation, or favoring by the United States Government or any agency thereof or its contractors or subcontractors.

Printed in the United States of America. To obtain copies of this document, contact: Document Control Services, P.D. Box 950, Mailstop H6-08, Richland WA 99352, Phone (509) 372-2420;

Fax (509) 376-4989.
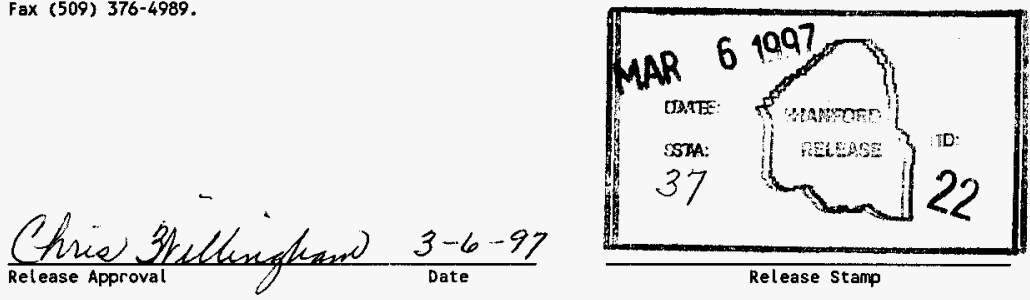

Approved for Public Release 
HNF-SD-SNF-TI-050, Rev. 0

\section{EXECUT IVE SUMMARY}

Nine outer fuel elements were recovered from the $K$ East Basin in the spring of 1996 and transferred to a hot cell for examination. Extensive testing planned for these fuel elements will support the preparations of the Safety Analysis Report and process design for the Integrated Process Strategy (IPS), with emphasis on drying and conditioning behavior.

Both in-basin and in-cell photography are presented to portray the physical condition of each of the fuel elements. These include full-length composites and selected close-ups of areas of particular interest.

Most of the fuel elements examined showed substantial physical damage, in conformance with the sampling objectives. However, two of the elements showed only moderate damage and one appeared to be still intact. Conditioning testing performed on these fuel elements with various damage levels will provide needed information for IPS process design guidance.

One of the test elements was found to be broken in two near its midsection when extracted from the shipping container. It is surmised that the breakage occurred either during shipping or during the difficult extraction process for this element.

When the lid was removed from the water-filled shipping container of one fuel element, considerable gas bubbling activity was noted. This bubbling activity ceased after a few hours, apparently due to air exposure in the hot cel1. 
HNF-SD-SNF-TI-050, Rev. 0

\section{EXECUTIVE SUMMARY (Continued)}

In general, hot cell observations of fuel element physical conditions were consistent with those expected based on in-basin observations made during the visual survey and sampling campaign. These examinations confirm that the fuel elements selected are appropriate to meet testing objectives to provide design guidance for IPS processing parameters. 
HNF-SD-SNF-TI-050, Rev. 0

\section{CONTENTS}

1.0 INTRODUCTION . . . . . . . . . . . . . . . . 6

2.0 PROCEDURE ........................... 7

3.0 FUEL ELEMENT $2214 \mathrm{E} \ldots \ldots \ldots$

4.0 FUEL ELEMENT $2350 \mathrm{E} \ldots \ldots \ldots 17$

5.0 FUEL ElEMENT $2540 \mathrm{E} \ldots \ldots \ldots 23$

6.0 FUEL ElEMENT $2711 \mathrm{E} \ldots \ldots . \ldots . \ldots . \ldots 30$

7.0 FUEL ELEMENT $3128 \mathrm{w} \ldots \ldots . \ldots 38$

8.0 FUEL ElEMENT $5069 \mathrm{E} \ldots \ldots . \ldots . \ldots 45$

9.0 FUEL ELEMENT $5427 \mathrm{E} \ldots \ldots \ldots$

10.0 FUEL ELEMENT $5608 \mathrm{E} \ldots \ldots \ldots 1$

11.0 REFERENCES .................... 66 


\section{LIST OF FIGURES}

1. In-Basin Sampling of 2214 E ................. 9

2. Precarious Attachment of 2214 E Outer Element Top End Cap . . . . 10

3. Annulus Between Inner and Outer Elements of $2214 \mathrm{E} \ldots \ldots . . . .11$

4. In-Cell Composites of $2214 \mathrm{E} \ldots \ldots 12$

5. Top End of $2214 \mathrm{E}$ at $0^{\circ}$ Orientation ............ 13

6. Top End of $2214 \mathrm{E}$ at $90^{\circ}$ Orientation Showing Fue 1 Voiding . . . 14

7. Bottom End Breach on $2214 \mathrm{E} \ldots \ldots 15$

8. Corrosion Pit on $2214 \mathrm{E}$ Located $10 \mathrm{in}$. from Bottom at $0^{\circ} \ldots 16$

9. In-Basin Sampling of $2350 \mathrm{E} \ldots \ldots 18$

10. In-Cel1 Composites of 2350 E . . . . . . . . . . . 19

11. Top End of $2350 \mathrm{E}$ at $0^{\circ}$ Orientation ............ 20

12. Roller Marks on 2350 E Fuel Element. ............ 21

13. Top End Break on $2350 \mathrm{E}$................ . . . 22

14. In-Basin Sampling of $2540 \mathrm{E}$............. . . 24

15. In-Cell Composites of $2540 \mathrm{E}$. . . . . . . . . . . 25

16. Broken Section of 2540 E Placed Atop Main Section . . . . . . 26

17. Broken Bottom End of $2540 \mathrm{E}$. . . . . . . . . . . . 27

18. Broken Top End of 2540 E Main Section . . . . . . . . . 28

19. Circumferential Cracks on $2540 \mathrm{E}$. . . . . . . . . . . . 29

20. In-Basin Sampling of $2711 \mathrm{E} \ldots \ldots 31$

21. In-Cel1 Composites of $2711 \mathrm{E} \ldots \ldots 32$

22. Highty Damaged Upper End of 2711 E Showing Fuel Voiding . . . . . 33

23. Fuel Pieces Fallen from $2711 \mathrm{E} \ldots \ldots$. . . . . . . . . . 34

24. Accumulated Fuel Fragments Collected from $2711 \mathrm{E}$. . . . . . . 35

25. Material Collected from Density Canister Holding 2711 E . . . . 36 


\section{LIST OF FIGURES (Continued)}

26. Debris Collected from the SFEC Holding 2711 E . . . . . . . 37

27. In-Basin Sampling of 3128 W . . . . . . . . . . . 39

28. In-Cell Composites of $3128 \mathrm{~W} \ldots \ldots 40$

29. Handling Scratches in Coating on $3128 \mathrm{~W} \ldots \ldots 41$

30. Handling Scratches in Sludge Ring on $3128 \mathrm{~W} \ldots \ldots 42$

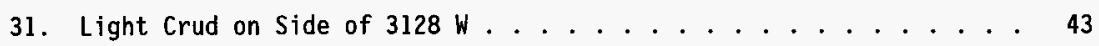

32. Crud B1isters Around Spacer Shoe on $3128 \mathrm{~W}$. . . . . . . . . . . . 44

33. In-Basin Sampling of $5069 \mathrm{E} \ldots \ldots 46$

34. In-Cell Composites of $5069 \mathrm{E} \ldots \ldots 47$

35. Through-Wall Penetration Along Side of $5069 \mathrm{E} \ldots \ldots 48$

36. Bottom End of 5069 E Before Element Drop . . . . . . . . . 49

37. Bottom End of 5069 E After Element Drop . . . . . . . . . . 50

38. In-Basin Sampling of $5427 \mathrm{E} \ldots \ldots . \ldots 2$

39. Circumferential Crack Near Mid-Section of 5427 E . . . . . . . 53

40. Distorted Inner $\mathrm{Cladding}$ on $5427 \mathrm{E} \ldots \ldots . . . \ldots 4$

41. Flaring Tool Used to Expand Inner Diameter of $5427 \mathrm{E} . \ldots . . .55$

42. In-Ce11 Composites of Top End of $5427 \mathrm{E} \ldots \ldots 56$

43. In-Cell Composites of Bottom End of $5427 \mathrm{E} \ldots \ldots 57$

44. Broken Bottom of 5427 E Top Section . . . . . . . . . 58

45. Broken Top of 5427 E Bottom Section ............ 59

46. Rejoined Sections of $5427 \mathrm{E} \ldots \ldots 60$

47. In-Basin Sampling of $5608 \mathrm{E} \ldots \ldots 2$

48. In-Ce11 Composites of $5608 \mathrm{E} \ldots \ldots 63$

49. Cracked Lower End of $5608 \mathrm{E} \ldots \ldots 4$

50. Breach on Top End of $5608 \mathrm{E} \ldots \ldots 65$ 


\section{IN-CELL VISUAL EXAMINATIONS OF K EAST FUEL ELEMENTS}

\subsection{INTRODUCTION}

Nine outer fuel elements were recovered from the $K$ East Basin in the spring of 1996 and transferred to a hot cell for examination. Extensive testing planned for these fuel elements will support the preparations of the Safety Analysis Report and process design for the Integrated Process Strategy (WHC 1995). Examinations will focus on the quantity and content of the sludge that accompanies the fuel elements to the hot cells and whole element drying and conditioning testing. This report presents the results of the initial visual examinations conducted on these fuel elements upon removal from their shipping containers in the hot cell.

The fuel elements selected for the most part exhibited substantial physical damage, in conformance with the criteria specified in the Data Quality Objectives (Lawrence 1996). Visual examinations were conducted on eight of the nine fuel specimens. The fuel elements are identified by the canister barrel location from which they were taken. In numerical order, the fuel elements are $2214 \mathrm{E}, 2350 \mathrm{E}, 2540 \mathrm{E}, 2711 \mathrm{E}, 3128 \mathrm{~W}, 5069 \mathrm{E}, 5427 \mathrm{E}$, and $5608 \mathrm{E}$. The "E" and "W" indicators refer to the east or west barrels of the canisters as they were stored in their basin cubicles.

For each fuel element examined, photographs are included that show the appearance of the element as it was extracted and loaded into its shipping container in K East Basin. The hot cell photographs are full length composite side views taken at 90 degree intervals, as well as top and bottom end views. Selected closeups are also included for areas of particular interest. 


\subsection{PROCEDURE}

During the in-basin fuel sampling, the inner element was removed (if possible) from the outer element, and the outer element was then extracted from the canister and transferred to the shipping container, which was termed a Single Fuel Element Canister (SFEC). The SFECs containing the fuel elements immersed in water were then shipped to the hot cell in a cask. When the SFEC lid was removed in the hot cell, the container was observed for some time for possible gas bubbling. The fuel element was then extracted into the hot cell air atmosphere and allowed to dry. After marking the 0 and 90 degree orientations on the fuel element, it was visually examined and photographed, both by still camera and video tape. Full length side views were constructed by combining composite photos taken at four orientations 90 degrees apart.

When the visual examinations were completed, the fuel element was returned to its water-filled SFEC for storage prior to subsequent testing activities. 


\subsection{FUEL ELEMENT 2214 E}

When the attempt was made to remove the inner element from the outer element during fuel sampling in the K East Basin, the outer element was lifted with the inner element. As shown in Figure 1, the inner element hooked the partially detached top end cap of the outer element. Accordingly, both elements were placed in the shipping container together and shipped to the hot cell. The views shown in Figure 1 indicate there is substantial peeling of the outer element cladding at the top end with the underlying fuel missing. Also, there is a prominent sludge ring about 2 in. high at the bottom of the outer element.

No bubbles were observed in the SFEC when the 1 id was removed in the hot cell. The inner and outer elements were again lifted together from the SFEC. Figure 2 shows the precarious attachment of the top end cap to the outer element cladding during lifting, but it did hold and the elements were successfully removed from the SFEC. End on viewing confirmed that the annulus between the inner and outer elements was clear of foreign material, as depicted in Figure 3.

The elements were separated horizontally in the hot cell by extracting the inner element out the bottom of the outer element. The composite photos of the $2214 \mathrm{E}$ outer element are presented in Figure 4 . Notebook entries made during the visual examinations indicated the element had a generally tan/white appearance with the exception of the dark band at the bottom. A close up view of the ruptured top end at the $0^{\circ}$ orientation is shown in Figure 5 . Another view of the top end at $90^{\circ}$ in Figure 6 shows there is substantial fuel voiding in this region.

The bottom end was also found to be breached. Figure 7 shows about a $1 / 2 \mathrm{in}$. long circumferential crack where the cladding is brazed to the end cap. No fuel loss was detectable from this area.

A number of corrosion type pits in the cladding were noted during the visual examinations. One of the larger ones (about $1 / 2$ in. diameter) is shown in Figure 8 . None of the pits observed showed any evidence of through-wall penetration. 


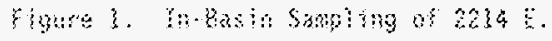

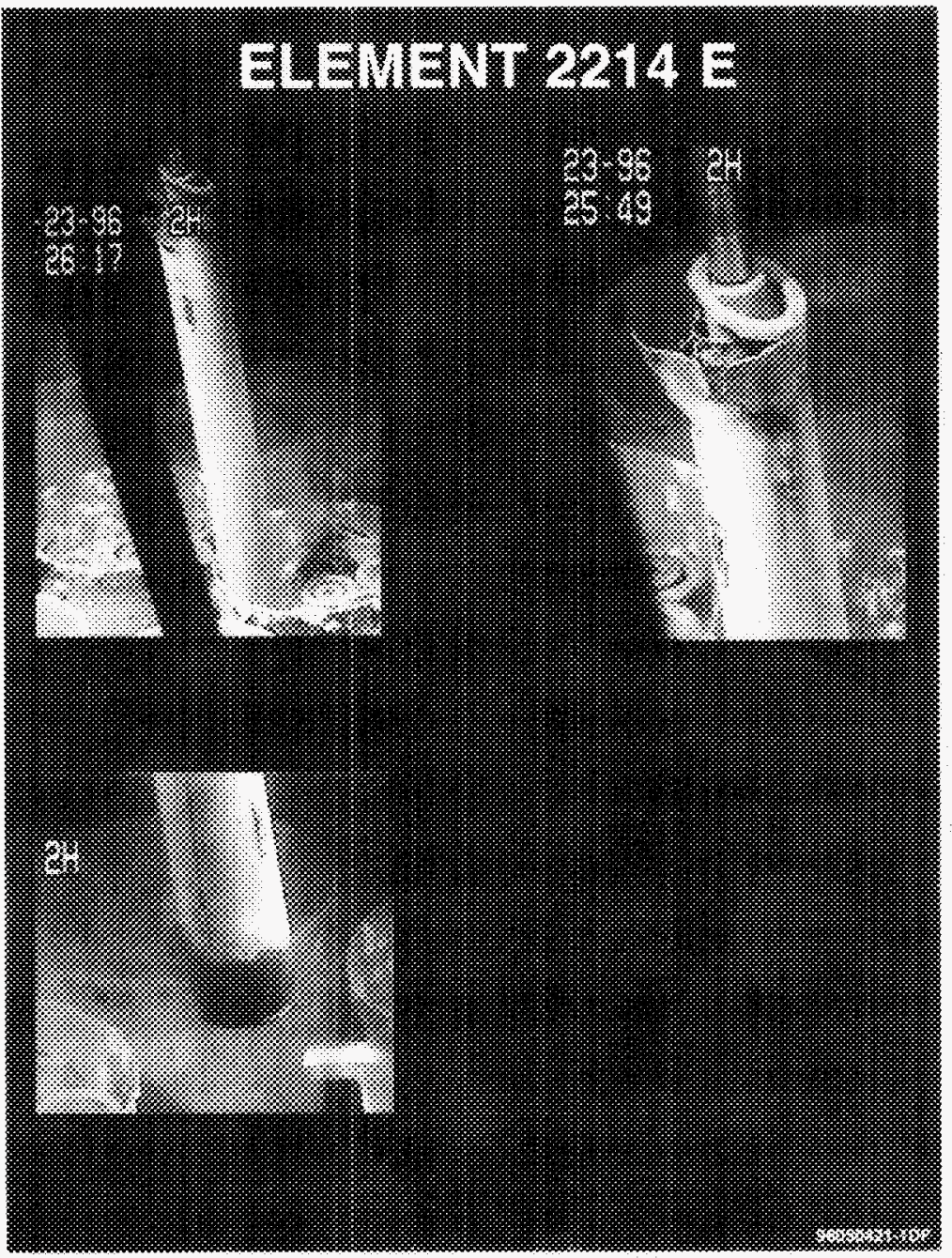




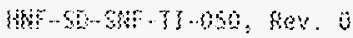

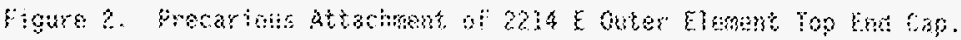

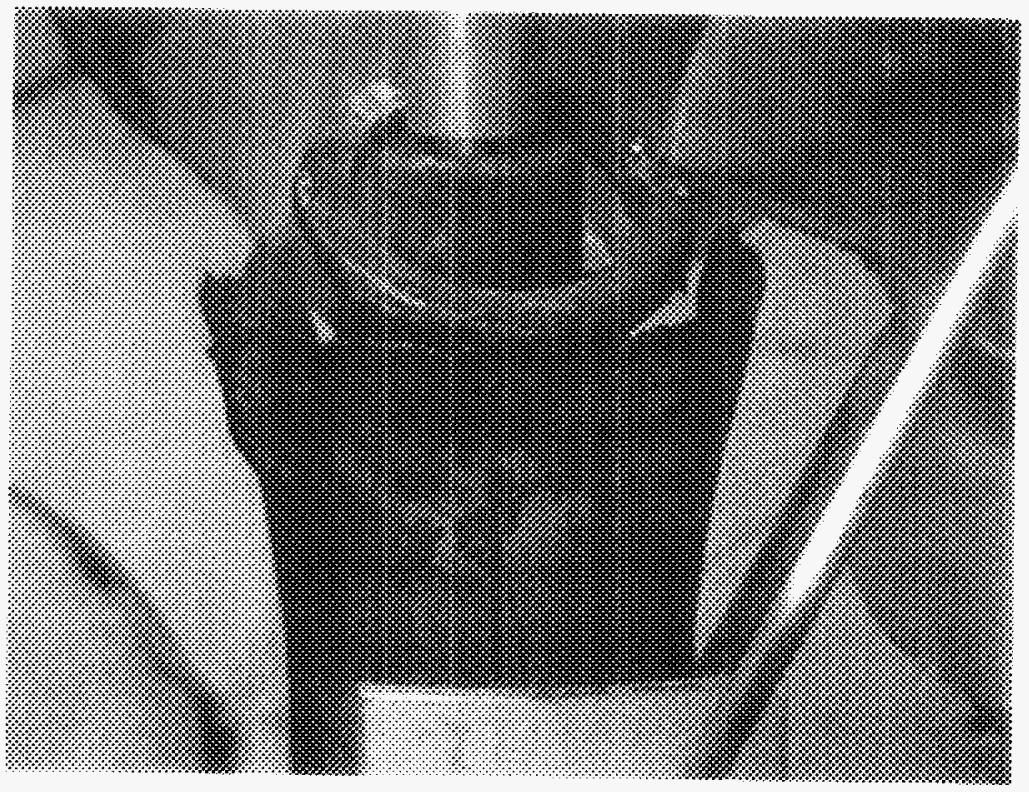




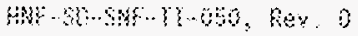

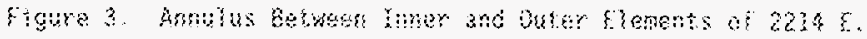

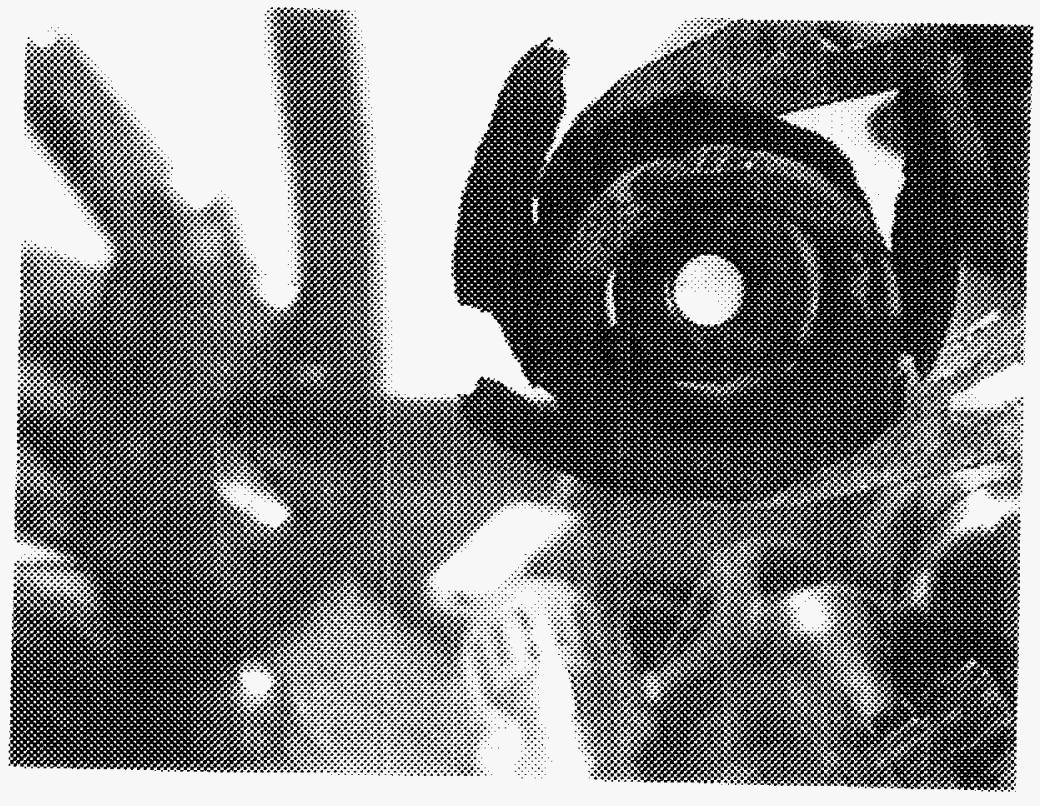




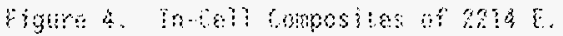

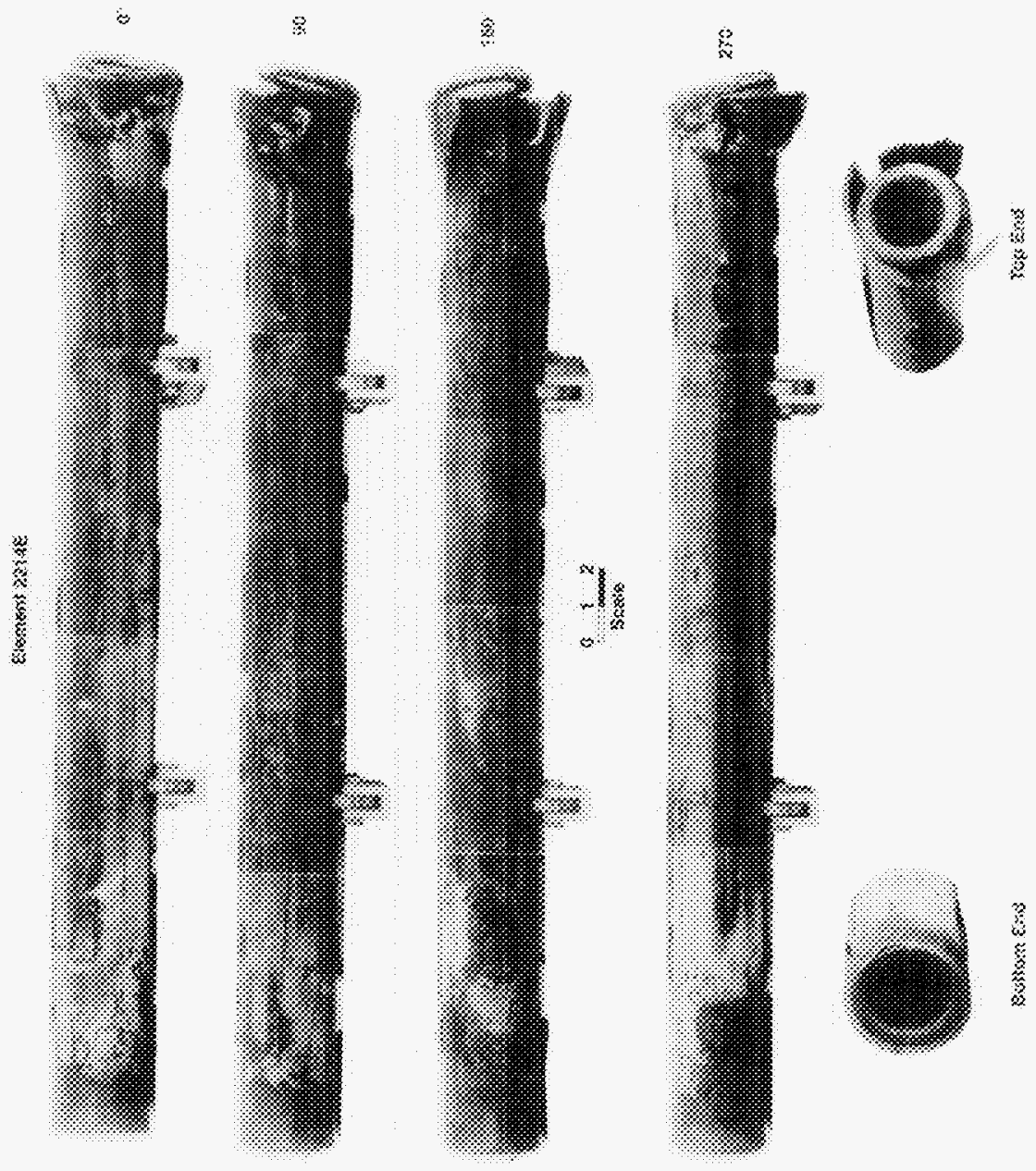




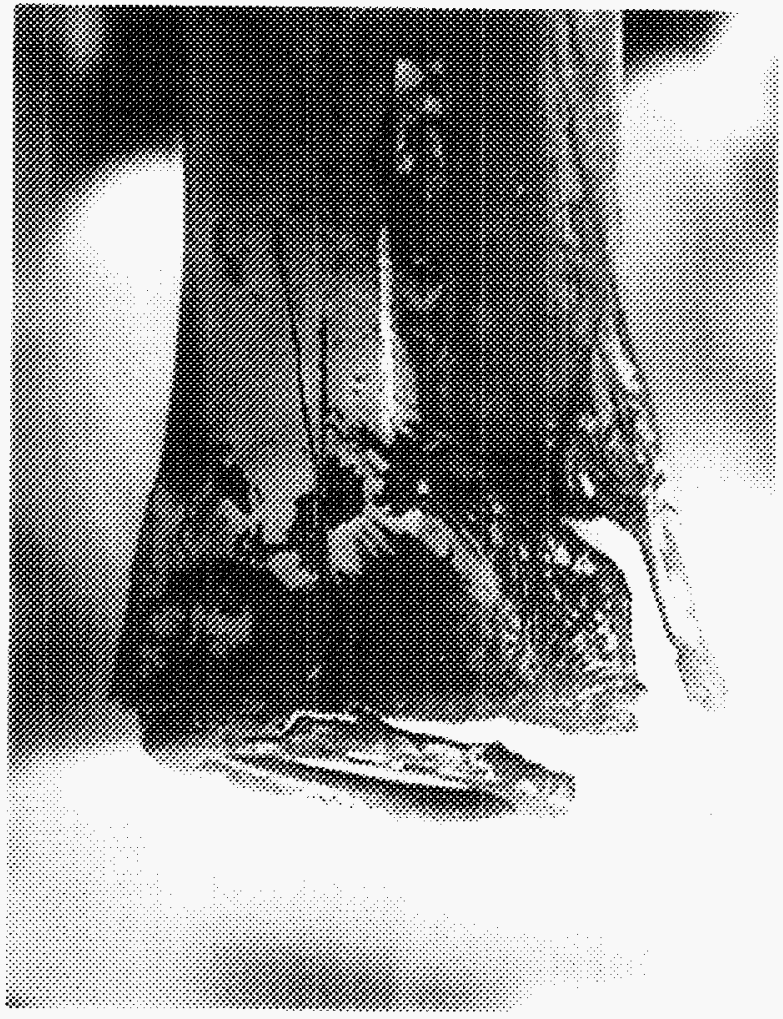

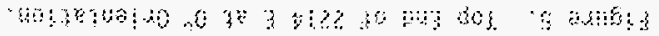

$$
\text { 6 } \operatorname{son} 690-11 \cdots 39-36-363
$$




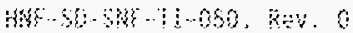

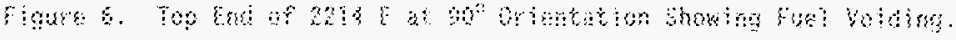

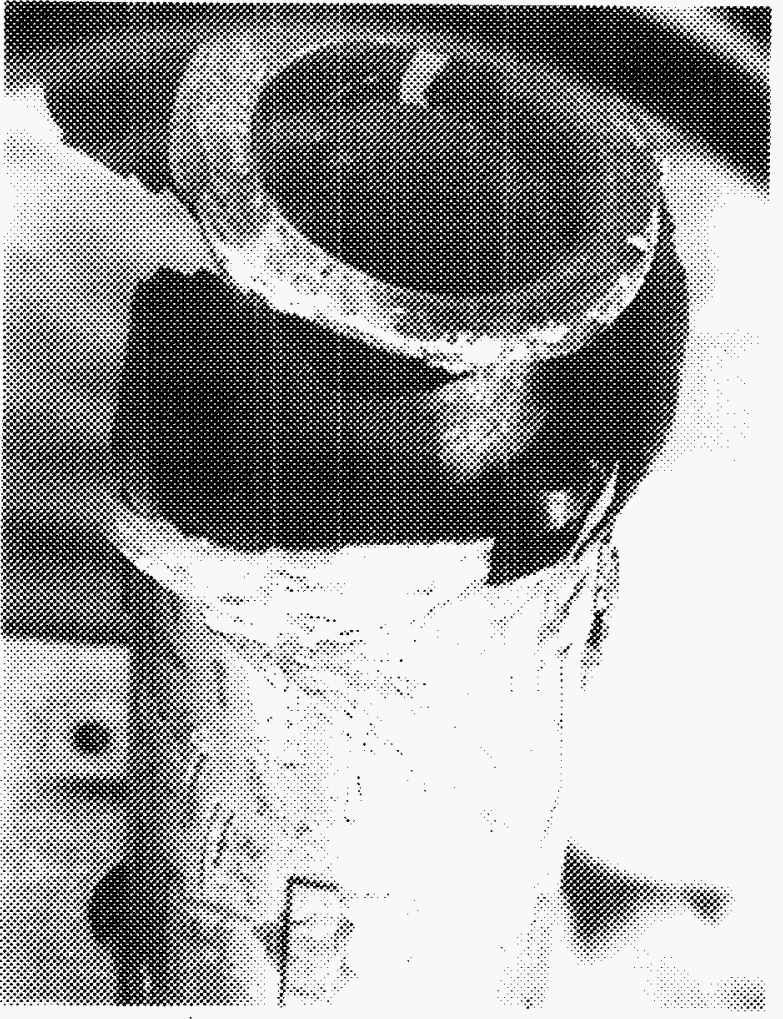




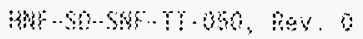

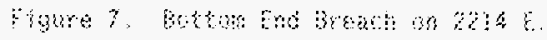

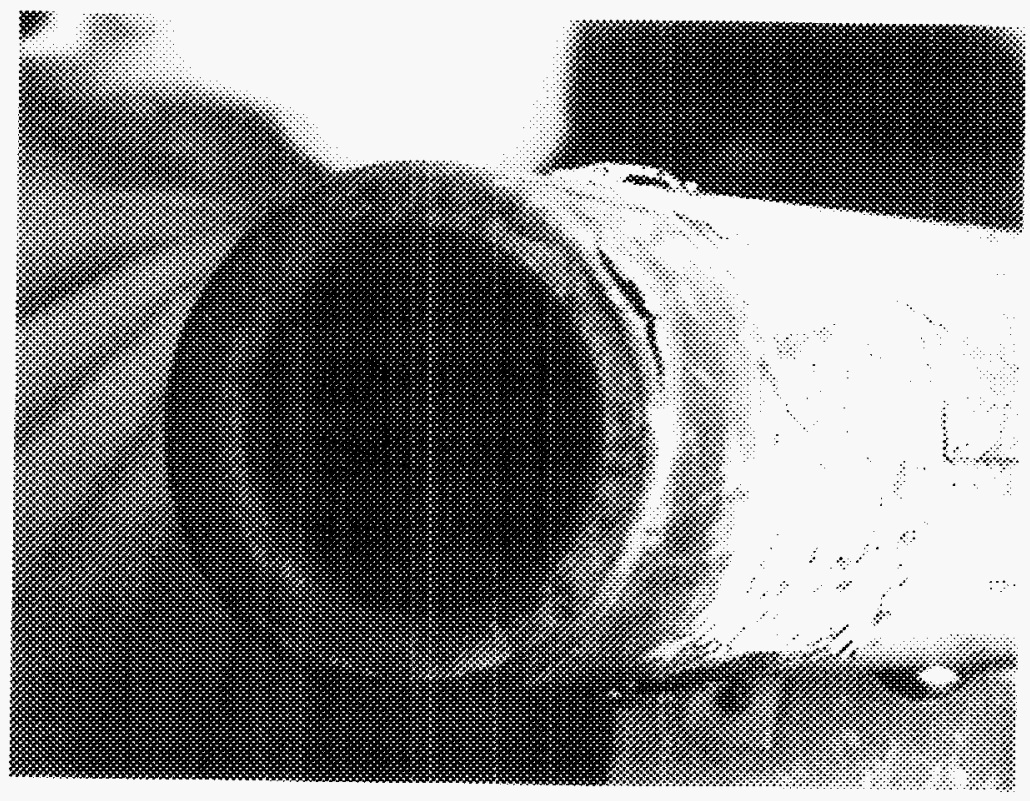




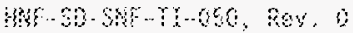

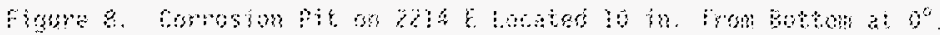

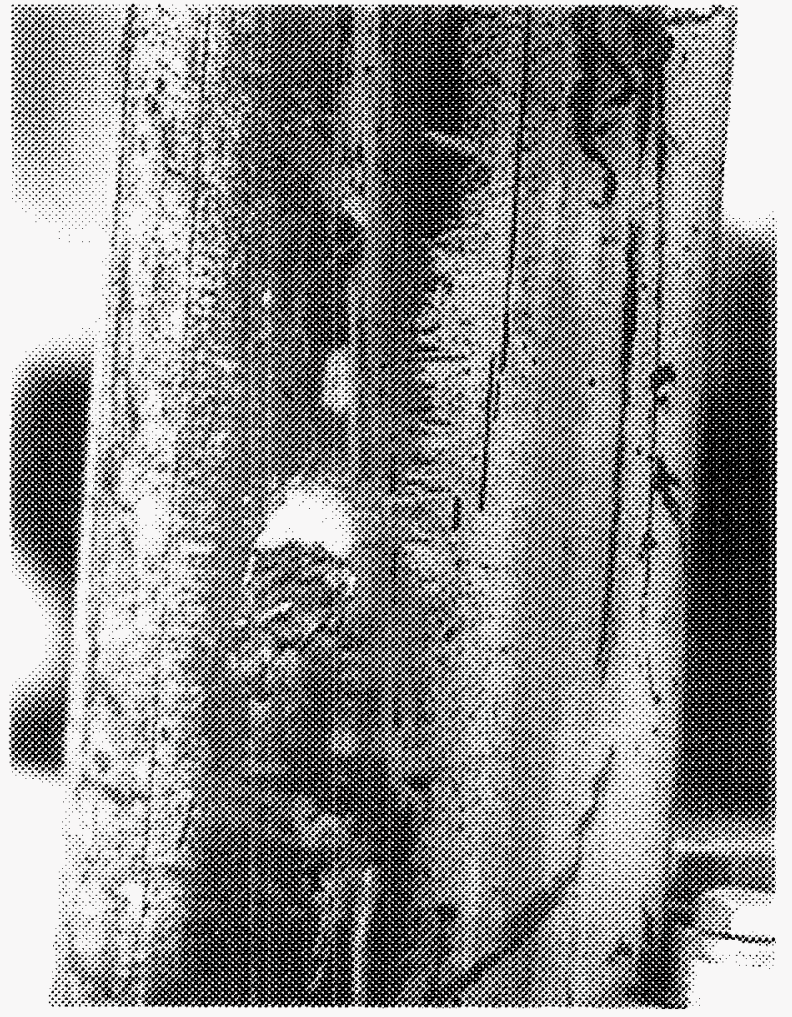




\subsection{FUEL ELEMENT $2350 \mathrm{E}$}

Extraction of the outer element sampled from $2350 \mathrm{E}$ canister in $\mathrm{K}$ East Basin is shown in Figure 9. It is apparent that the top of the element is broken in the vicinity of one of the spacer shoes. There is also a definite sludge ring at the bottom of the element.

No bubbling was observed in the SFEC when the lid was removed in the hot cell. However, some light particles were noted to be floating on top of the water.

Composite photos taken on the $2350 \mathrm{E}$ fuel element are shown in Figure 10. The top end photo at $0^{\circ}$ did not take, and a supplementary view made from videotape footage is shown in Figure 11 . Based on the locations of the remaining spacer shoes at the top end, it was determined that the break in the element occurred about 5 in. down from the top. The sludge band at the bottom of the element varied in height from about 1 to 3 in. The sludge ring profile on the element is presumed to reflect the sludge depth gradient in the canister where this element resided.

No pitting or corrosion was found on the $2350 \mathrm{E}$ fuel element. The element was noted to have a light white coating on it that was easily scratched. This is evidenced in Figure 12, where marks made by the rollers on the examination platform as the element was rotated are easily visible.

A close up view of the top end break is shown in Figure 13. The break appears to be relatively clean in nature. The exposed fuel seems to be fairly intact and there is little distortion of the cladding. 


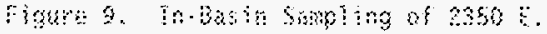

\section{ELEMENT $2850 \mathrm{E}$}
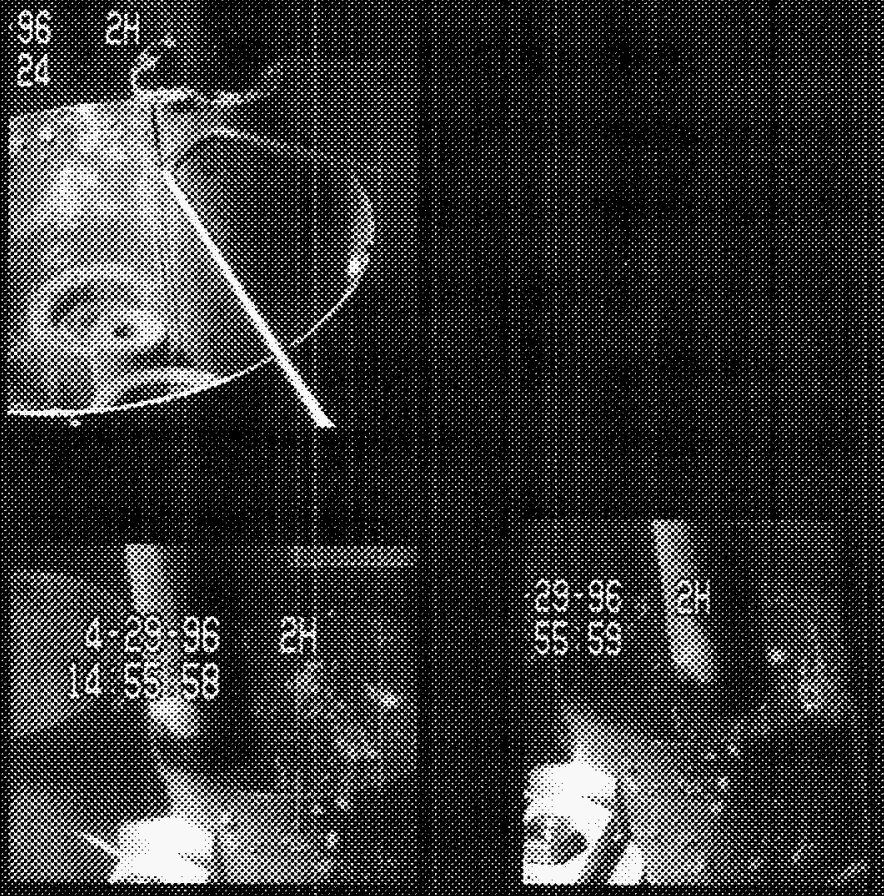
Wh5-36-SW-7:-60, Rey, D

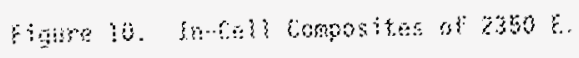

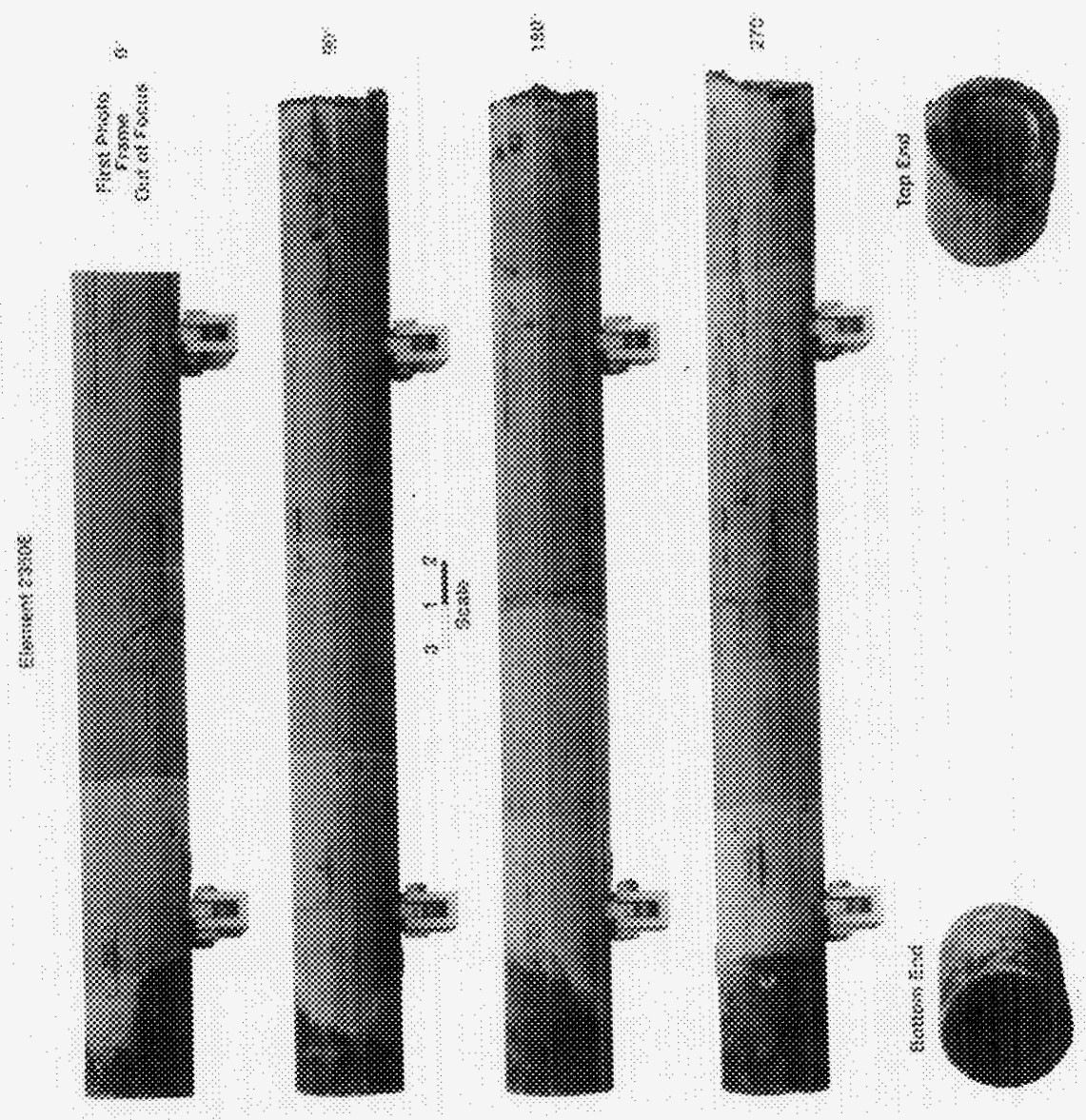




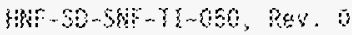

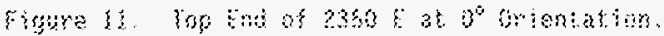

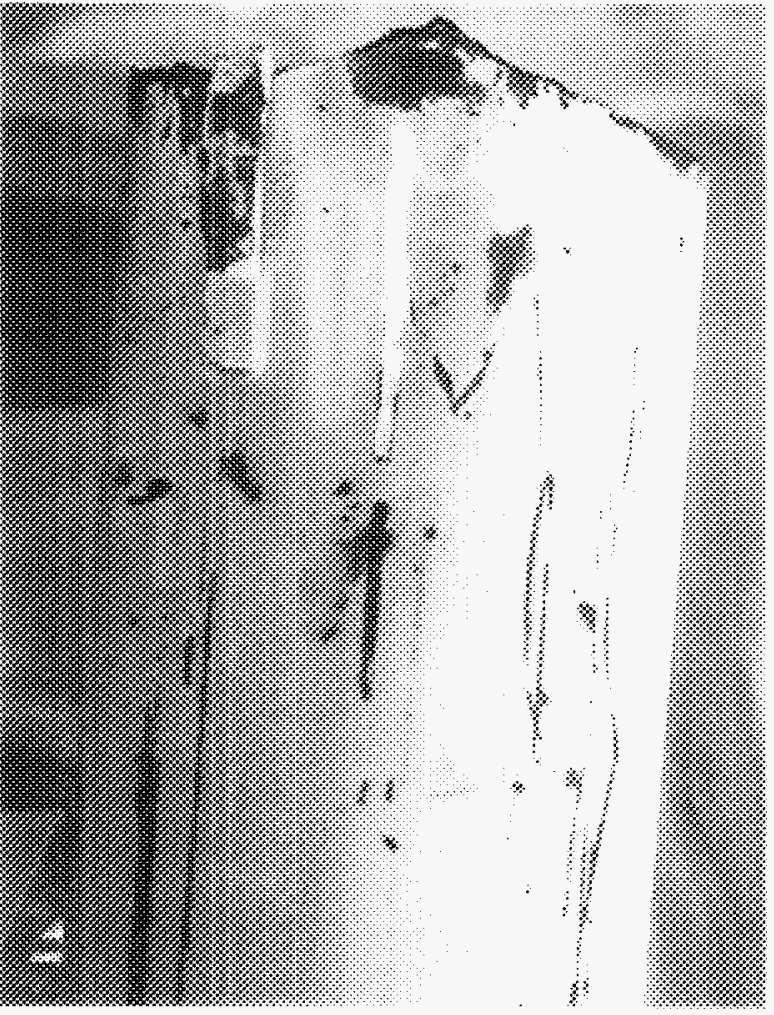




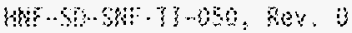

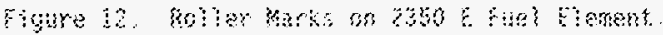

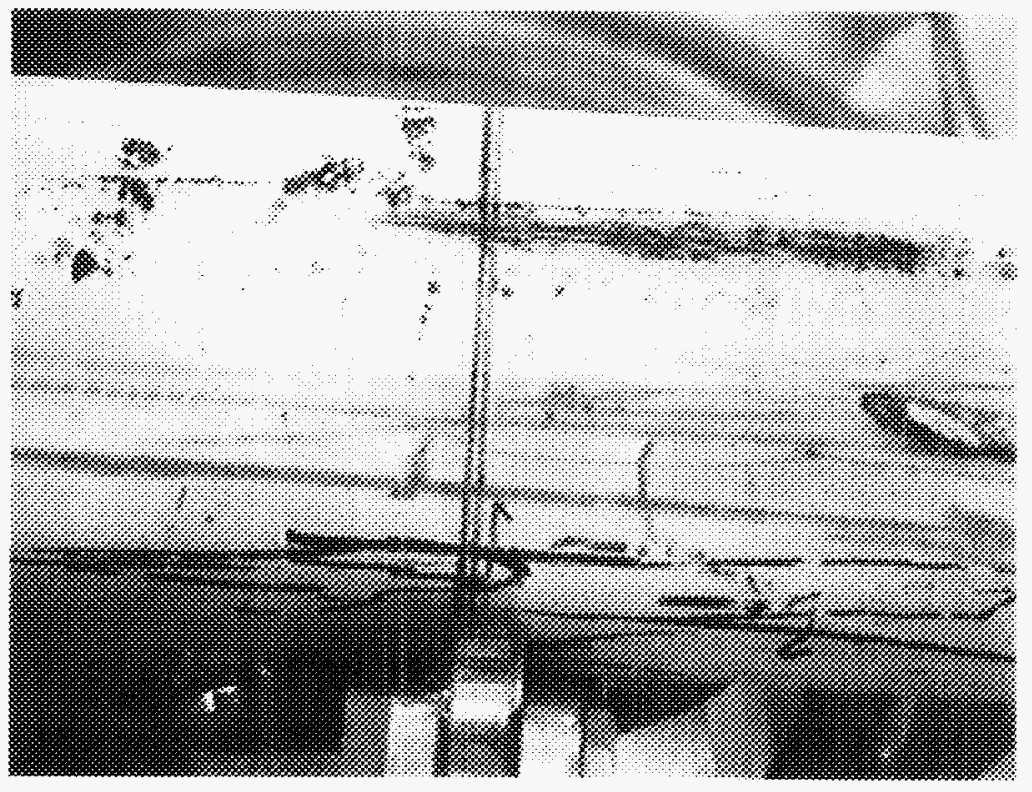


t46-50-54-15-060, for, 0

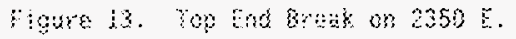

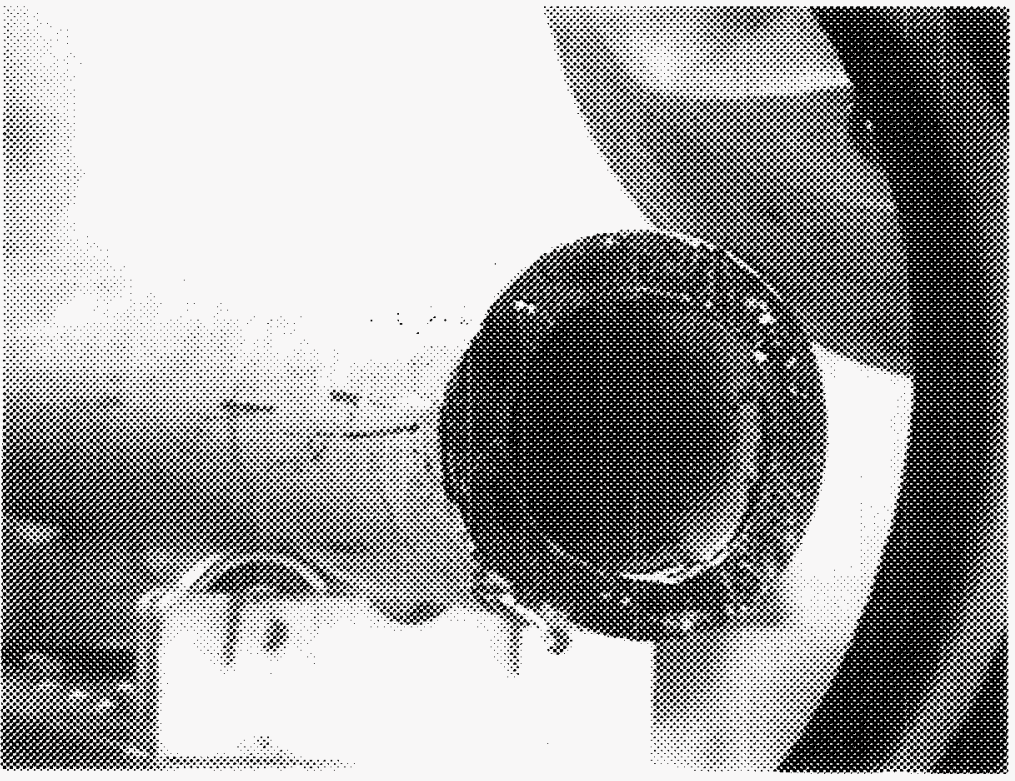




\subsection{FUEL ELEMENT 2540 E}

Photos of the K East Basin sampling of the fuel element from the $2540 \mathrm{E}$ canister are shown in Figure 14. The element was found to be broken at the bottom as it was extracted from the canister. The top end was also highly damaged, and during placement of the fuel element in the SFEC the top section (about 2 in.) broke off and remained on the grappling tool. This section was removed from the grappling tool and placed in the SFEC as well.

No bubbles were observed when the SFEC 1id was removed in the hot cell. Composite photos taken in the hot cell are shown in Figure 15. The fuel element in its present state is definitely seen to be broken on both ends. The remaining main section of the element is a little over $18 \mathrm{in}$. 1ong. This implies that the lower $\sim 6$ in. of element is missing. No lower end spacer shoes are present on the element.

The broken-off top section is shown in Figure 15 as well. In Figure 16, the broken top section has been temporarily placed atop the main element section.

A close up view of the broken bottom end is shown in Figure 17 . The fuel surface appears rough and pitted in this "old break." An end view of the freshly broken surface on the top end of $2540 \mathrm{E}$ is shown in Figures 18 . The surface is seen to have a much smoother texture in this "new break."

A number of cracks were observed on the fuel element. In Figure 19, two circumferential cracks near the midsection of the element are shown. These cracks extended around the full circumference of the element. 


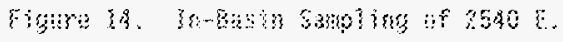

\section{ELEMENT $2540 \mathrm{E}$}
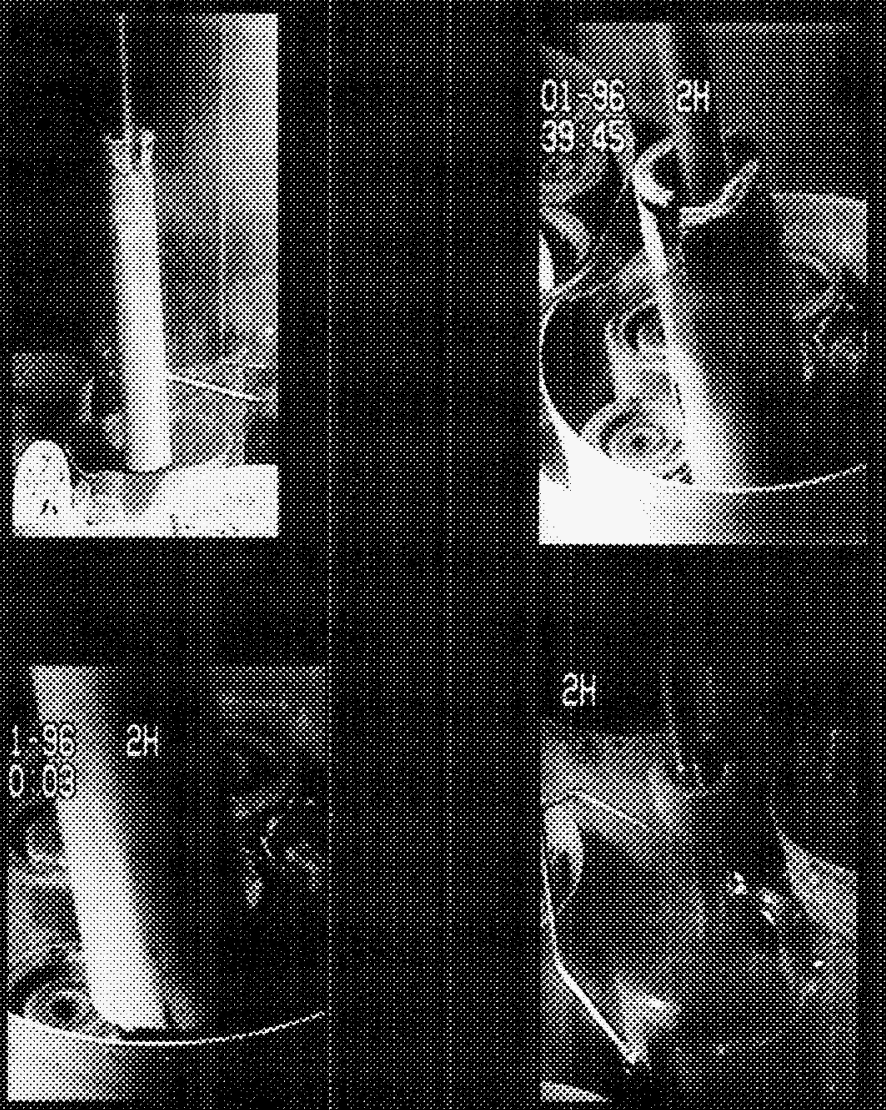


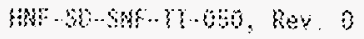

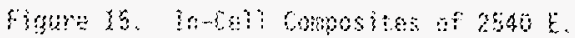

\author{
Shenent $2500 \mathrm{x}$
}
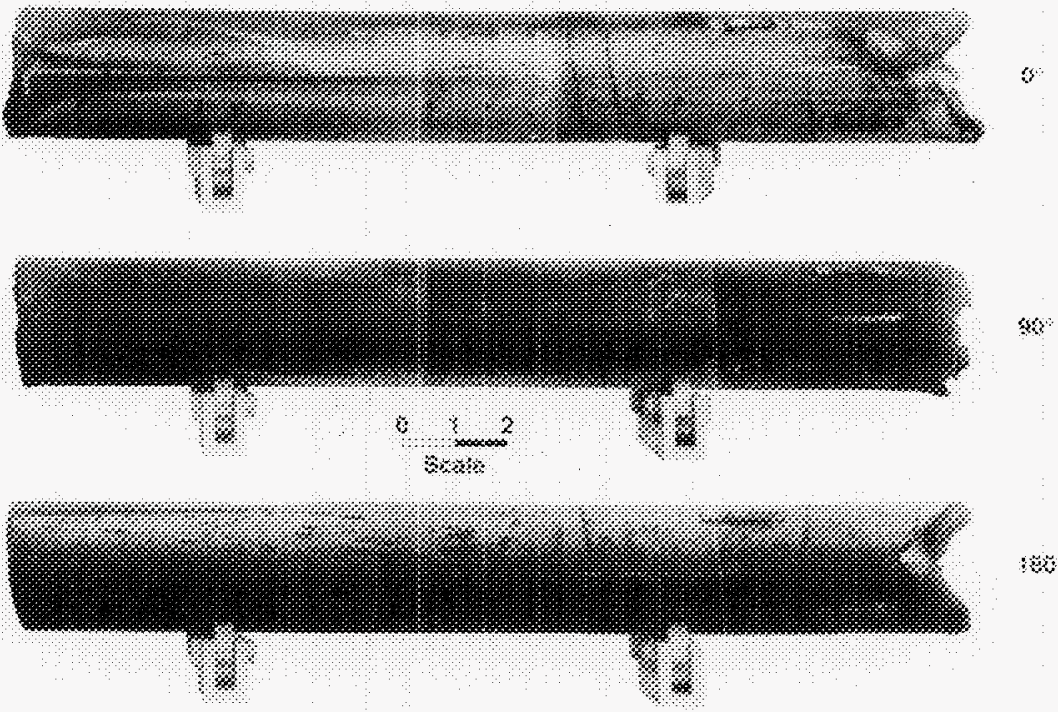

$58 \%$

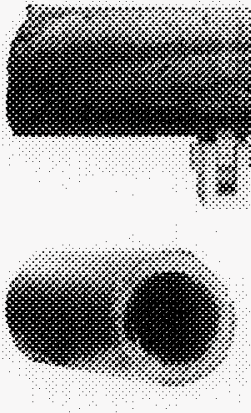

Bowhon sssos

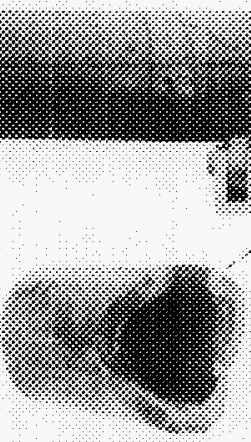

Ko, Lot

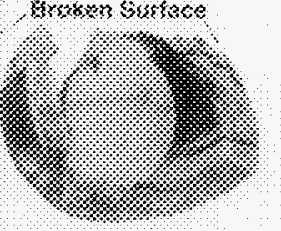

Kssp \&ss 


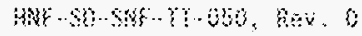

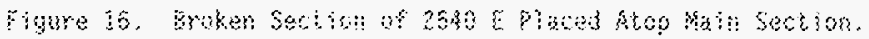

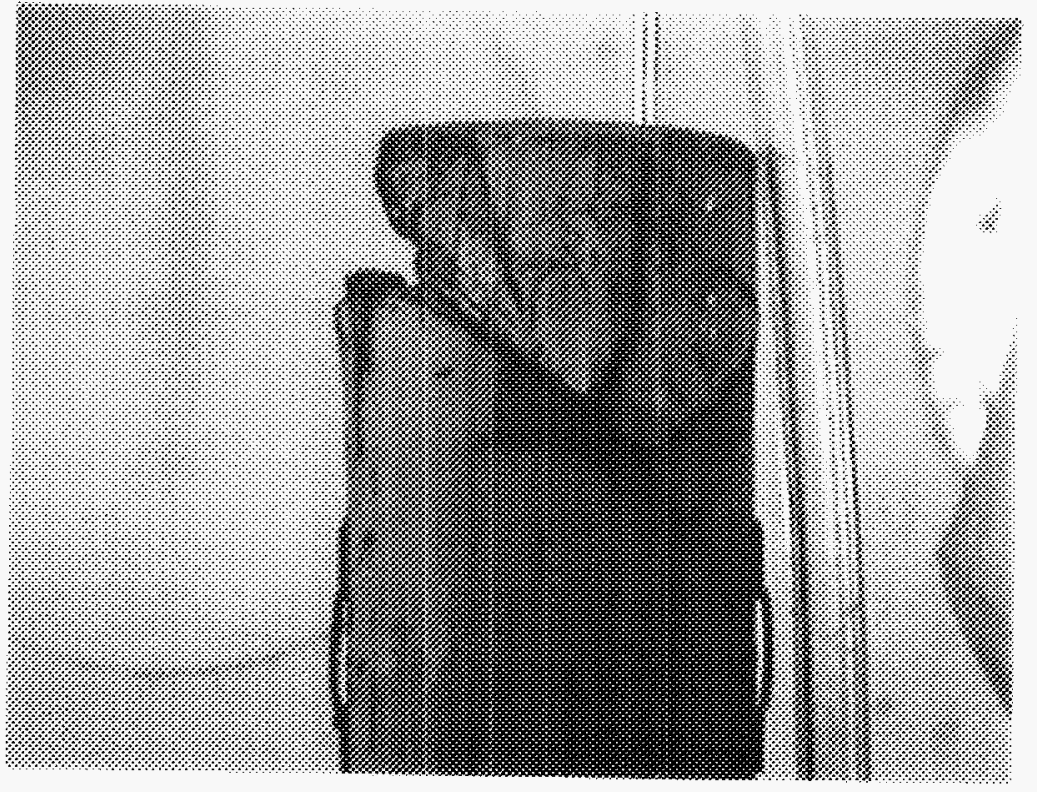




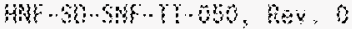

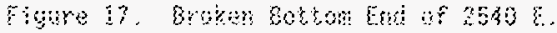

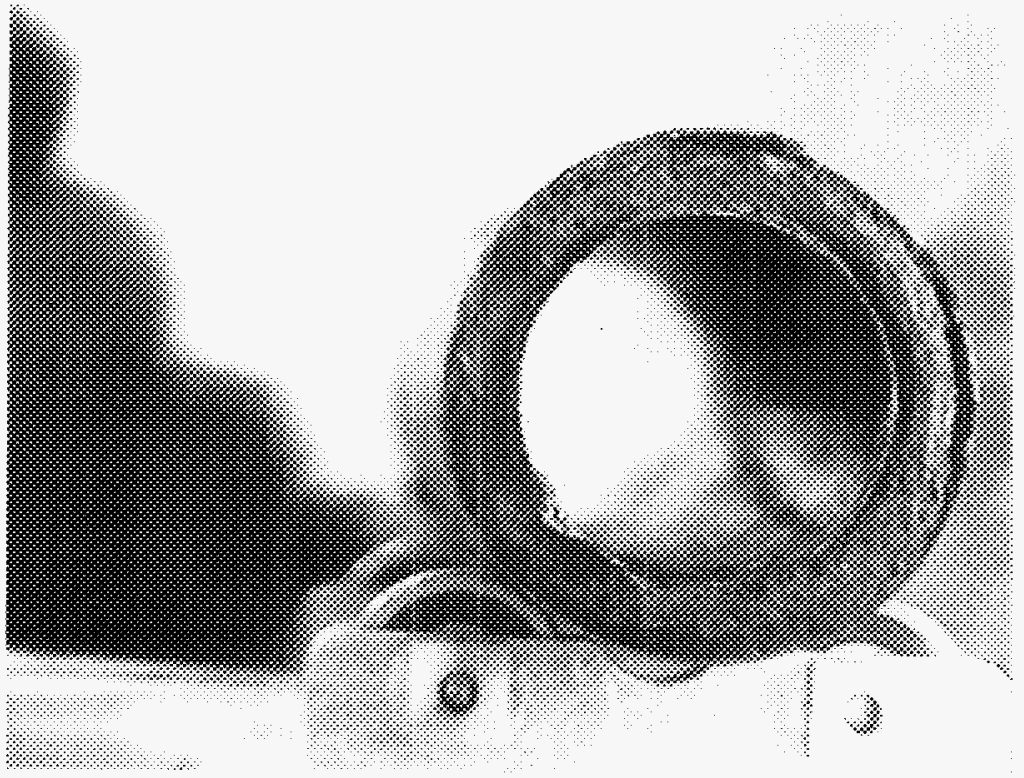




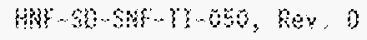

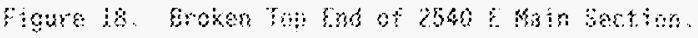

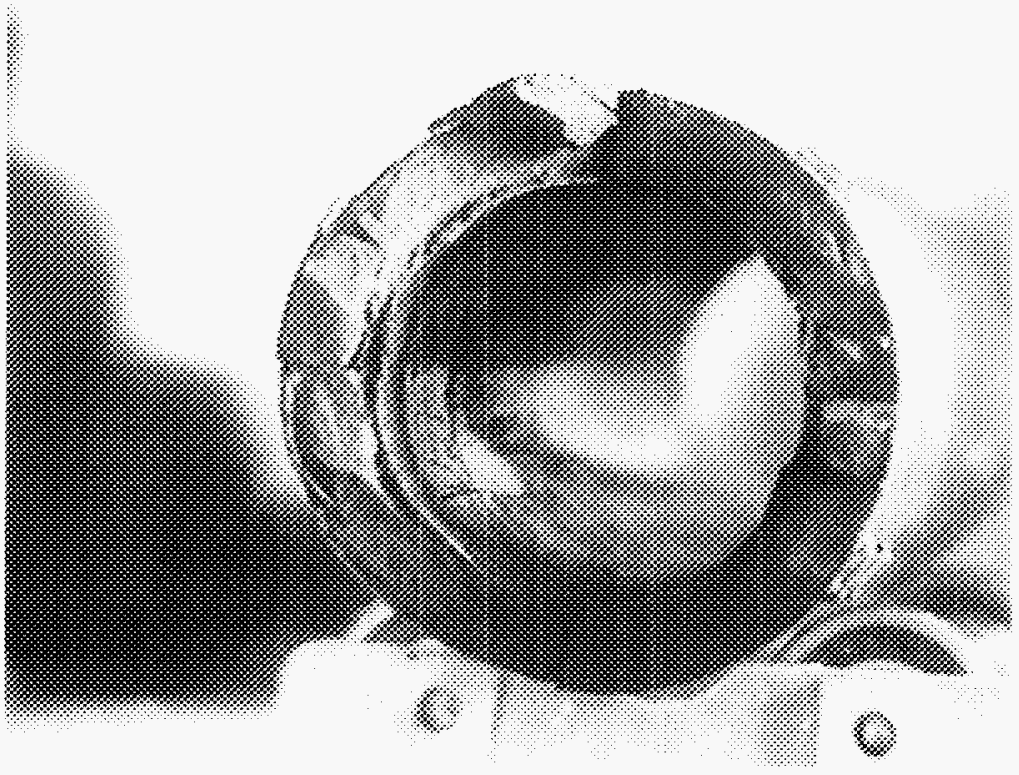




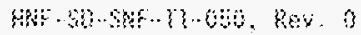

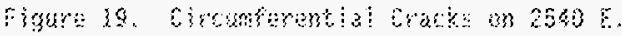

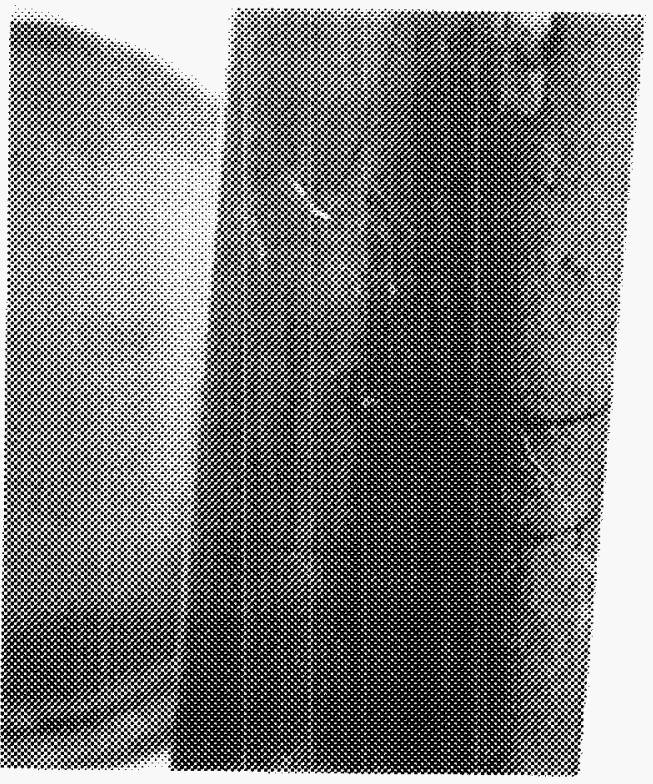


HNF-SD-SNF-TI-050, Rev. 0

\subsection{FUEL ELEMENT 2711 E}

The extraction of the $2711 \mathrm{E}$ fuel element from its canister in K East Basin is shown in Figure 20. The top end of the fuel element is seen to be highly damaged with peeled cladding and voided fuel. Sludge residue is visible at the bottom of the element.

When the lid was removed from the SFEC in the hot cell, surface scum was evident on top of the water. Considerable bubble activity was also noted, with small gas bubbles breaking the surface about once every second. This bubble activity continued for about two hours until the element was removed from the SFEC. When the attempt was made to return the element to the SFEC after the initial examinations, it could not be fully inserted, apparently due to interfering debris at the bottom of the SFEC. The element was subsequently placed in a water filled density canister for overnight storage. No bubble activity was noted while the fuel element was stored in the density canister. It is surmised that exposure to the hot cell air atmosphere terminated whatever activity it was that generated the gas bubbles, possibly due to the formation of a surface oxide layer sufficient to slow the reactions.

Composite photos of the $2711 \mathrm{E}$ fuel element are shown in Figure 21. The photographs confirm the high level of damage on the upper end, but show the lower end integrity to be relatively sound. It was estimated during the visual examinations that approximately half of the fuel in the upper section was missing. Figure 22 is a close up of the damaged upper end that illustrates the substantial degree of fuel voiding.

There was notable fuel loss incurred during handling of the fuel element in the hot cell. In Figure 23, several fuel pieces that fell from the element are seen lying on the viewing platform. About 15 such pieces were collected as they fell from the element, the largest being about 1 in, across as shown in Figure 24. The total volume of these escaped fuel fragments was estimated to be about $2 \mathrm{in}^{3}$, which would correspond to about $600 \mathrm{~g}$ of uranium mass.

Fuel material also apparently escaped from the fuel element during storage in the SFEC (includes shipment) and the density canister. The remnants from the density canister are shown in Figure 25 after being captured on a 6 in. diameter sieve of 38 micron mesh. This material appeared to be fine particle like sludge. The debris collected from the bottom of the SFEC is shown in a similar sieve in Figure 26. Sludge, fuel chunks, and a relatively large piece of $\mathrm{cladding}$ were collected from the bottom of the SFEC. Release of this fuel element from the grappling tool after transfer to the SFEC in K East Basin was very difficult, and entailed physical pounding on the element to achieve release. 


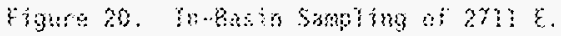

\section{ELEMENT $2711 \mathrm{E}$}
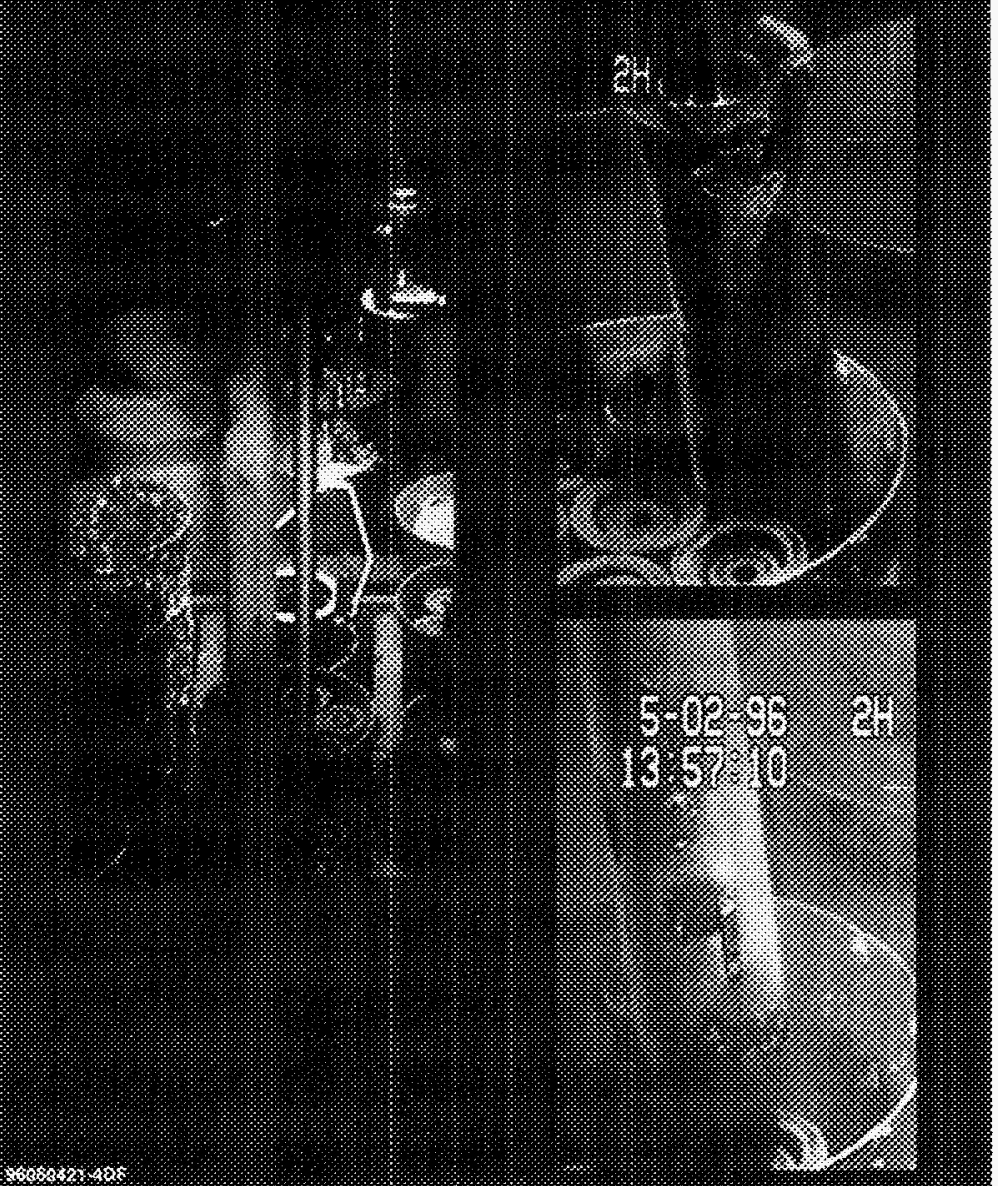


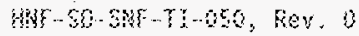

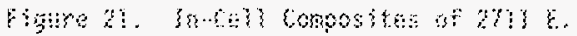
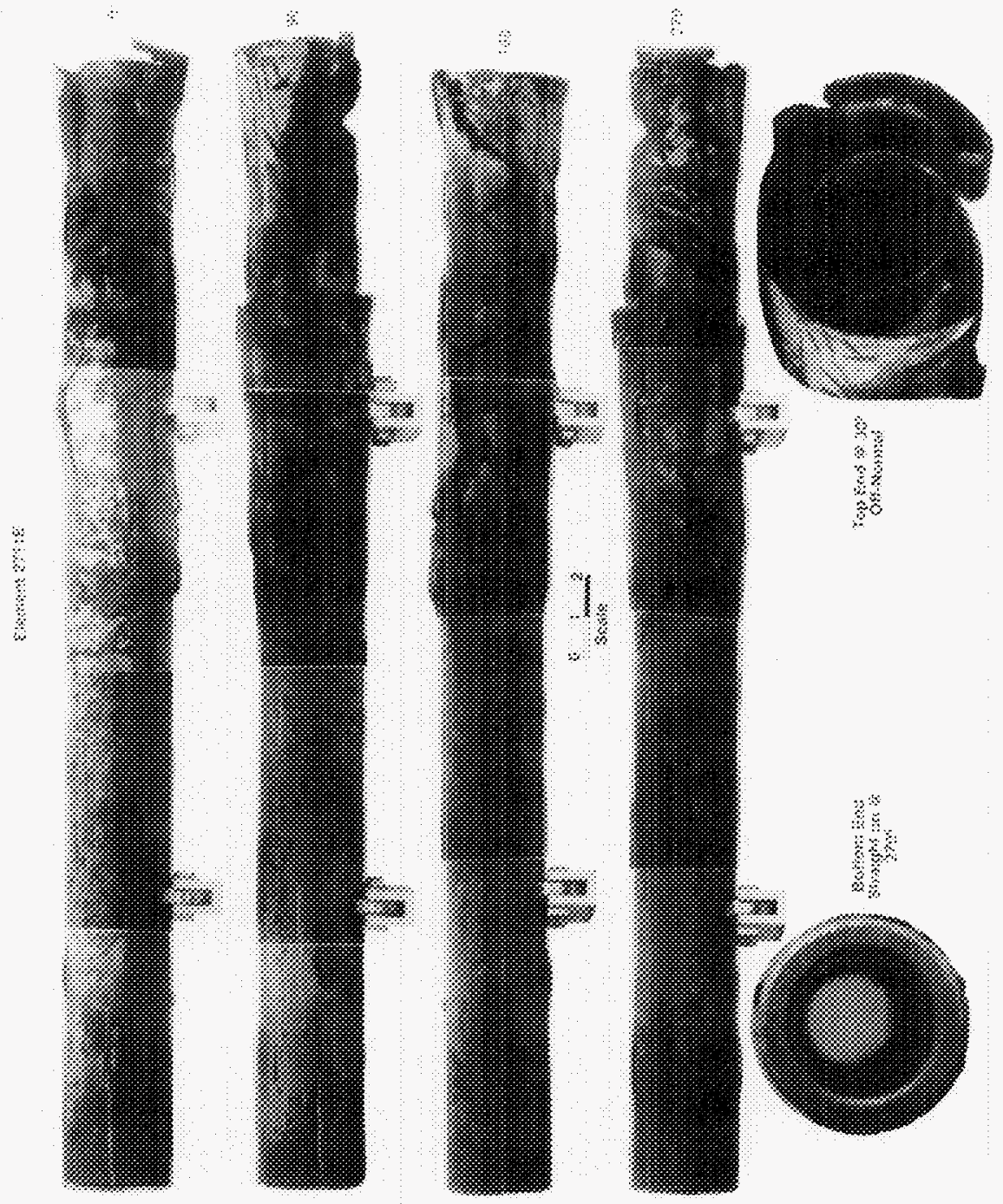


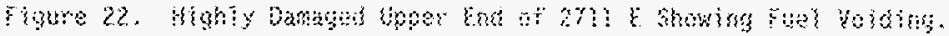

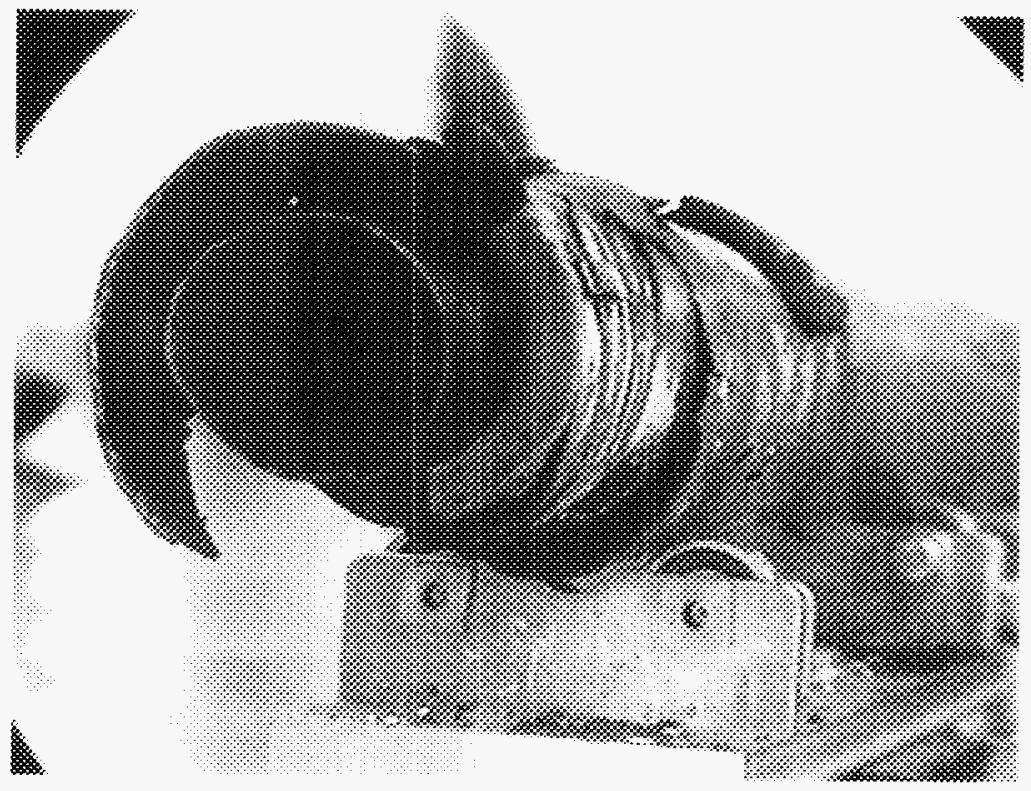




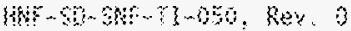

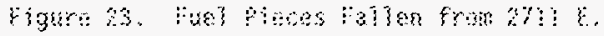

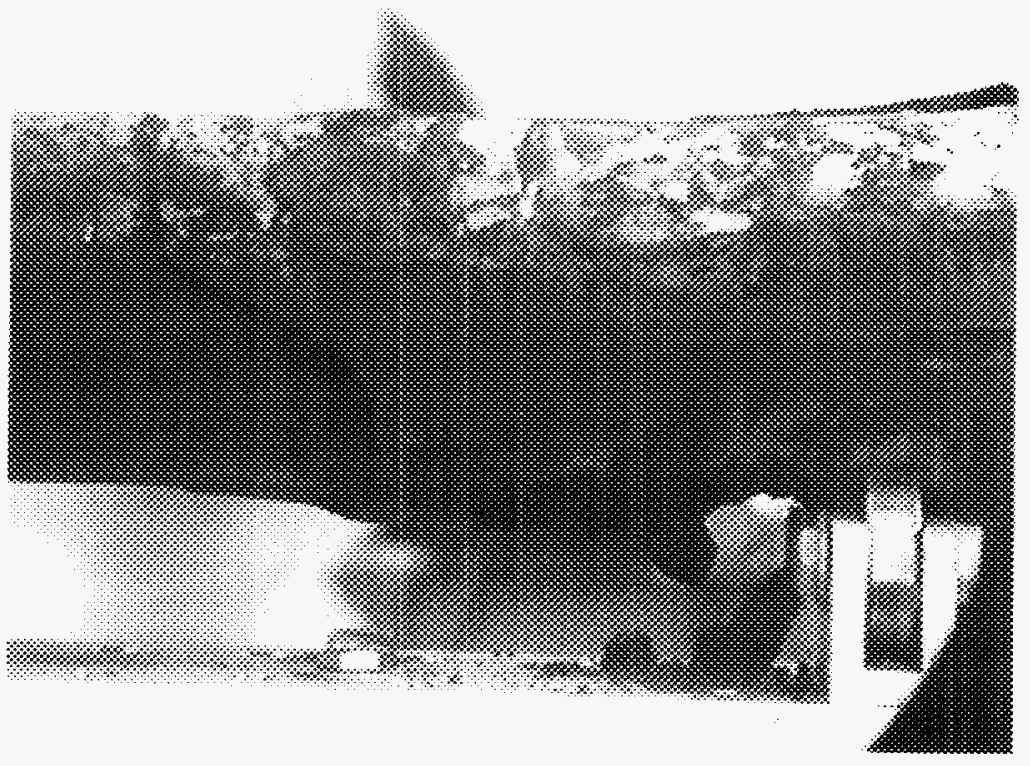


HF⿻

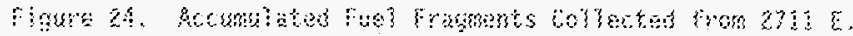

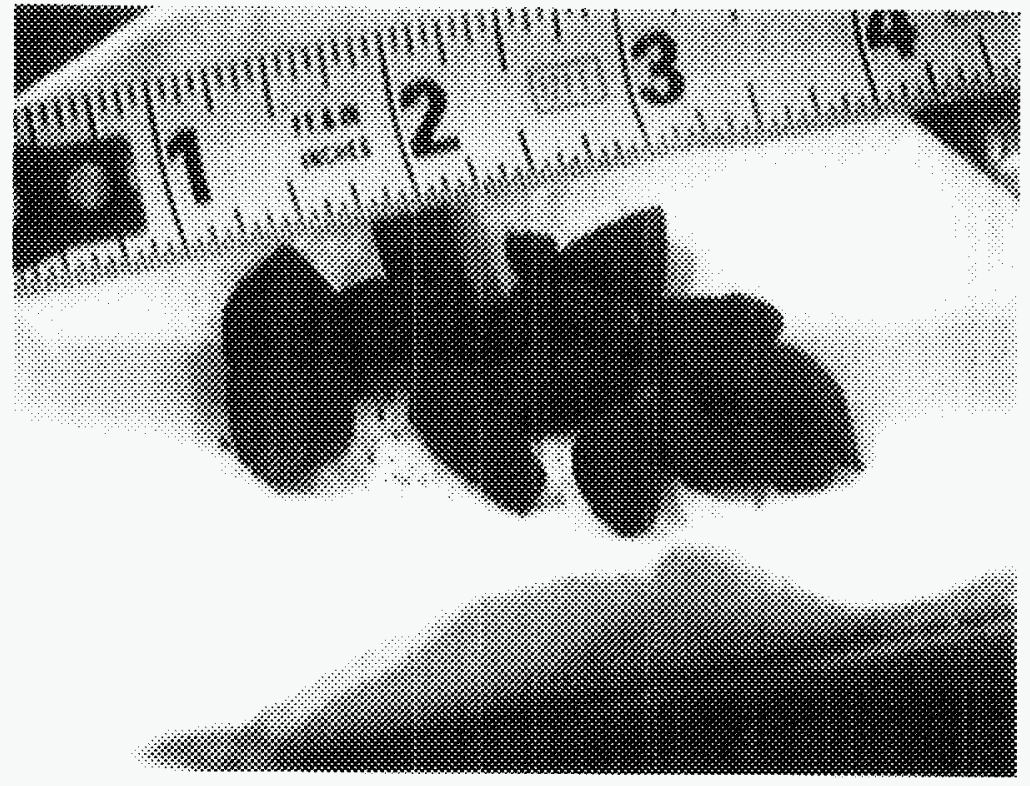




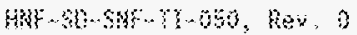

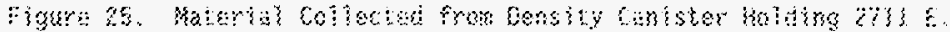

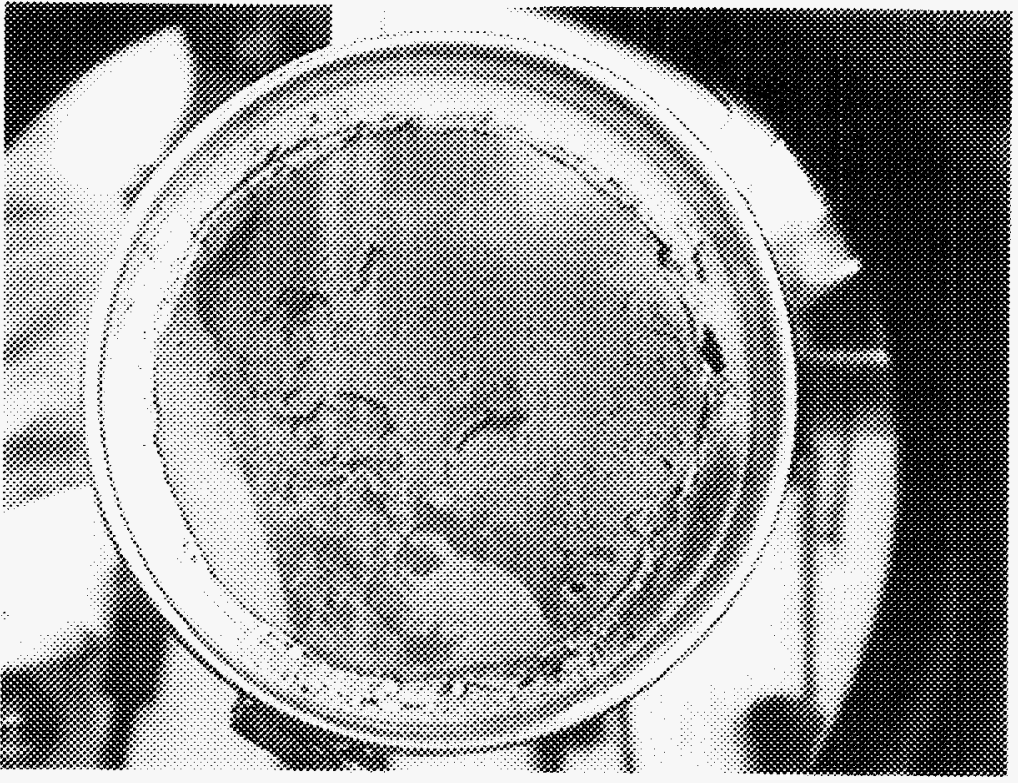




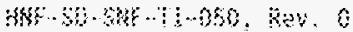

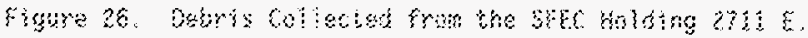

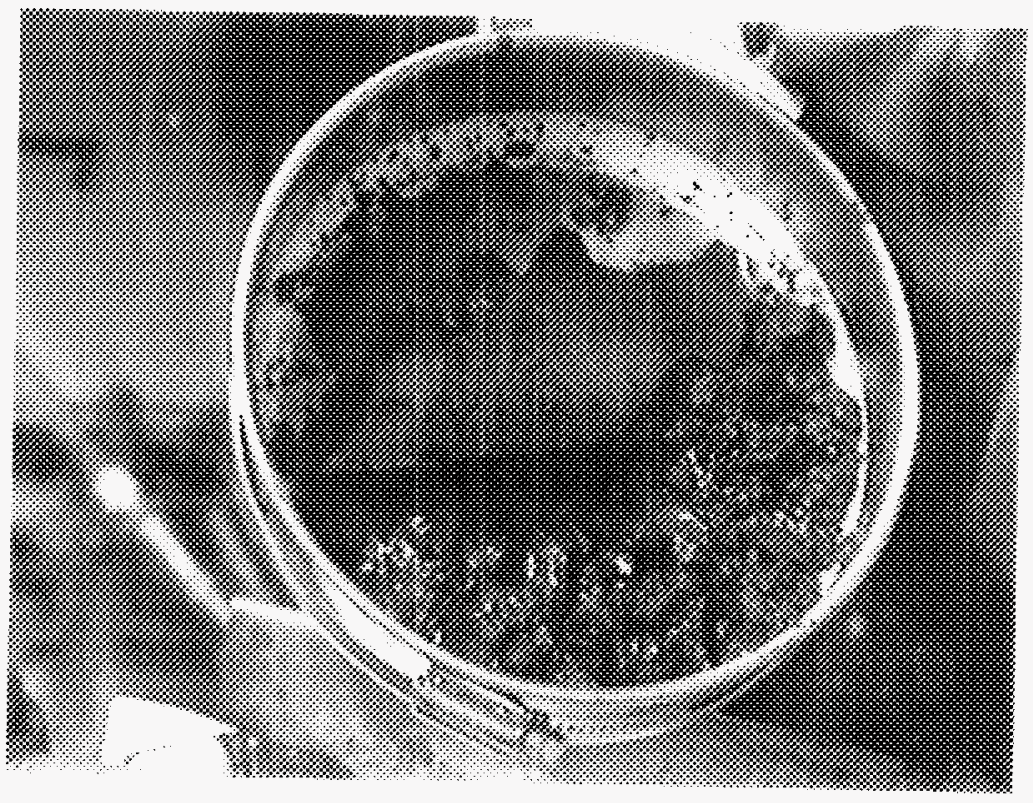




\subsection{FUEL ELEMENT 3128 W}

The extraction of the $3128 \mathrm{~W}$ element from its canister in $\mathrm{K}$ East Basin is shown in Figure 27. Although the element left a substantial sludge trail as it was lifted from its storage canister, there is no apparent damage visible in the photographs of Figure 27 . There does appear to be a significant sludge ring at the bottom of the element, consistent with the notable sludge trail left behind the element as it was extracted and transferred to the SFEC.

No bubbles were observed when the lid was removed from the SFEC. Composite photos of $3128 \mathrm{~W}$ taken in-cell are shown in Figure 28 . No significant damage was found on the element during the visual examinations. There was a sludge ring that covered the bottom 2 in. of the element, and extended up about $7 \mathrm{in}$. on the $90^{\circ}$ orientation side. The light colored coating which covered the element was easily scratched during handling, as depicted in Figure 29, where a roller bearing mark and longitudinal scratches apparently inflicted during element extraction are evident. The sludge ring at the bottom was also easily scratched, as shown in Figure 30.

Visual observations during examination noted the presence of a light, fluffy type crud on the element, mostly towards the bottom. This crud is shown in Figure 31 along with the upper extension of the sludge ring. A heavier type of crud was also present in the vicinity of the upper spacer shoe at the $270^{\circ}$ orientation, as shown in Figure 32. There appeared to be no penetration of the cladding associated with these crud blisters. 


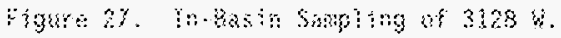

\section{ELEMENT $3128 \mathrm{~W}$}

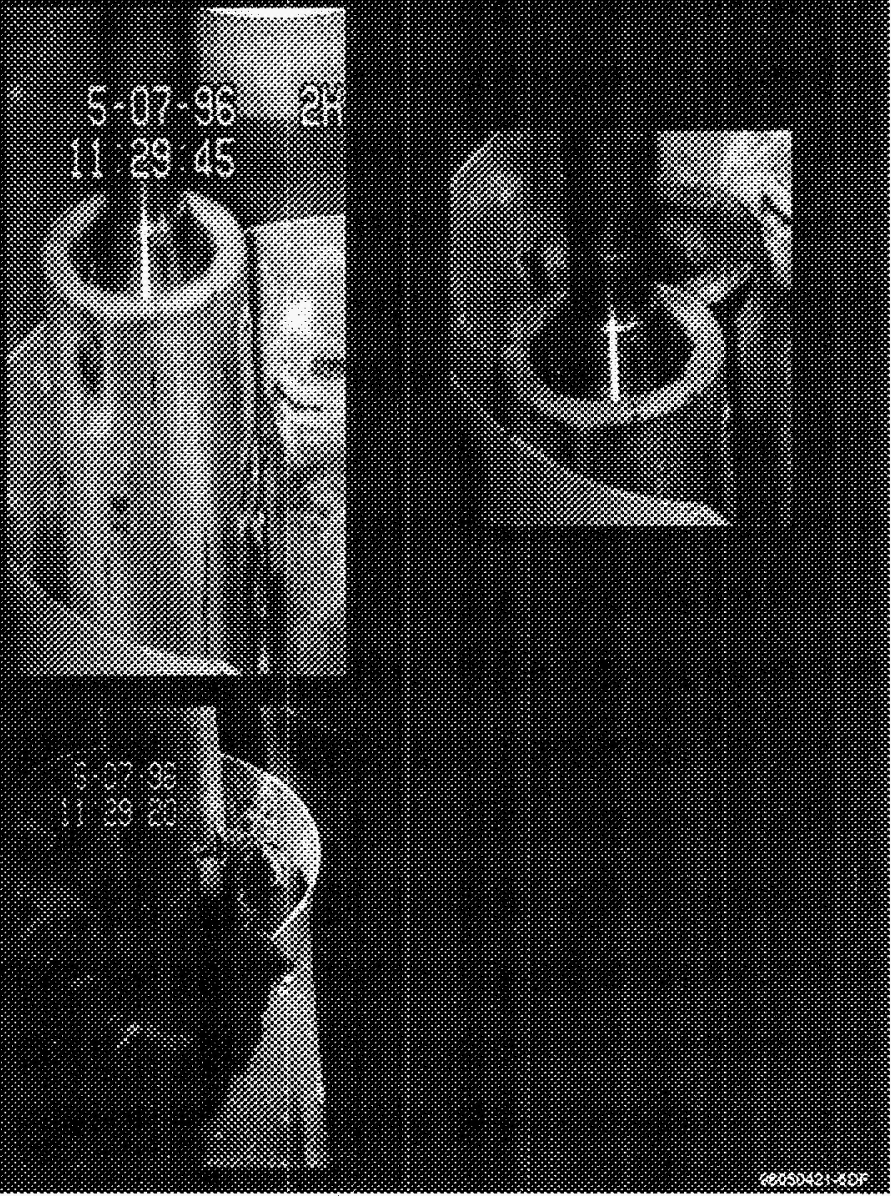




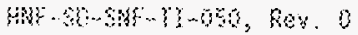

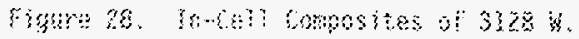
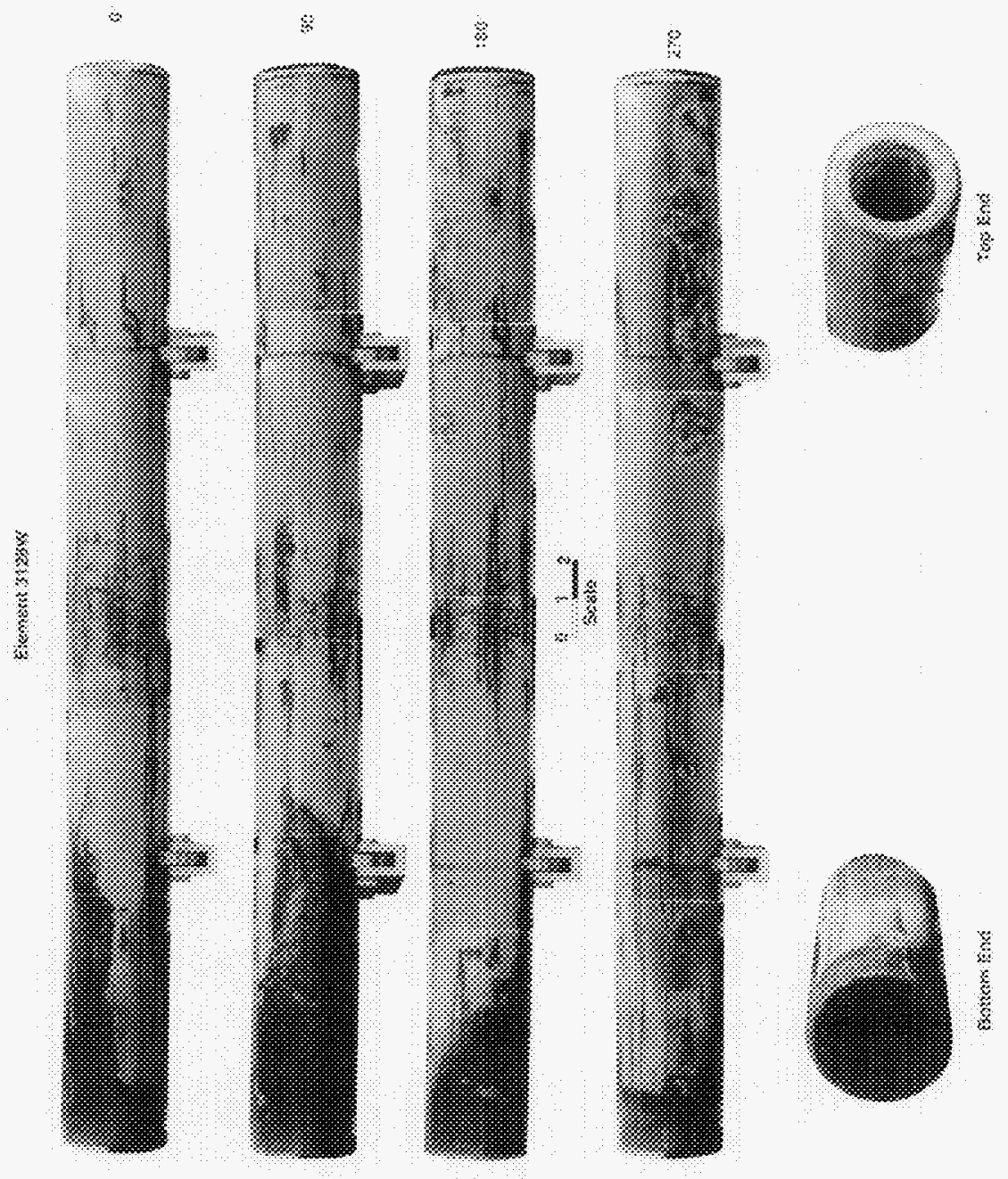


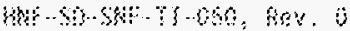

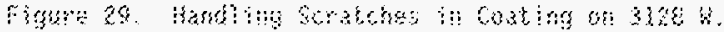

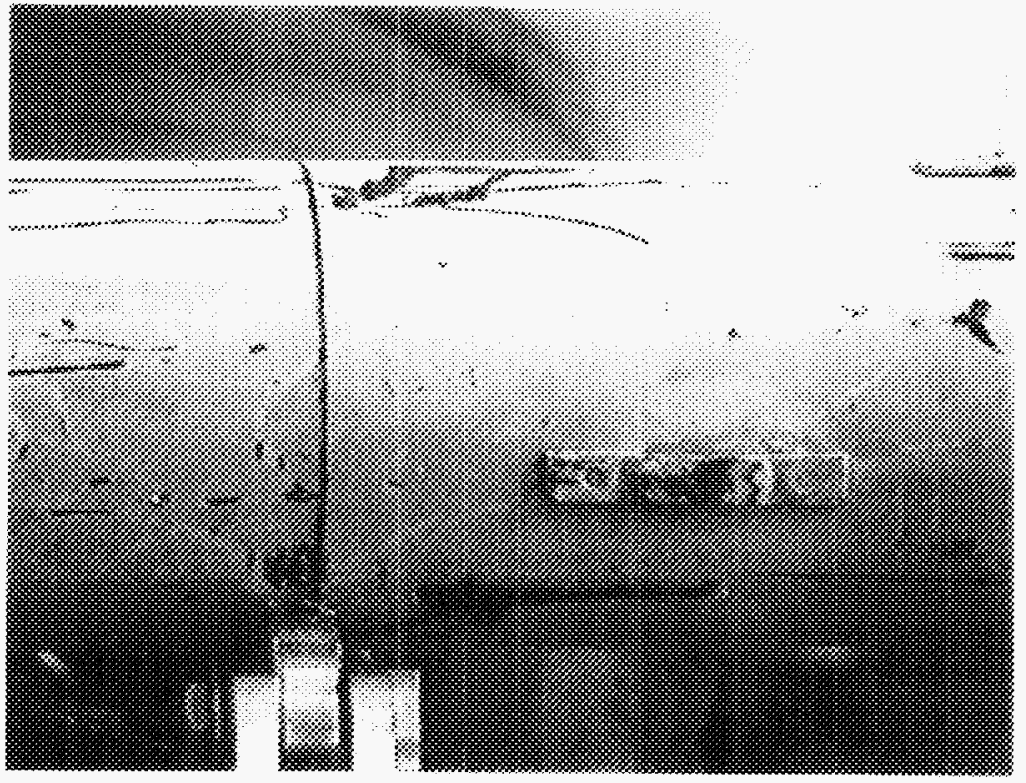




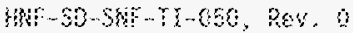

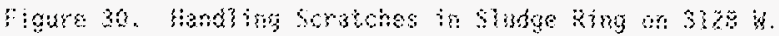

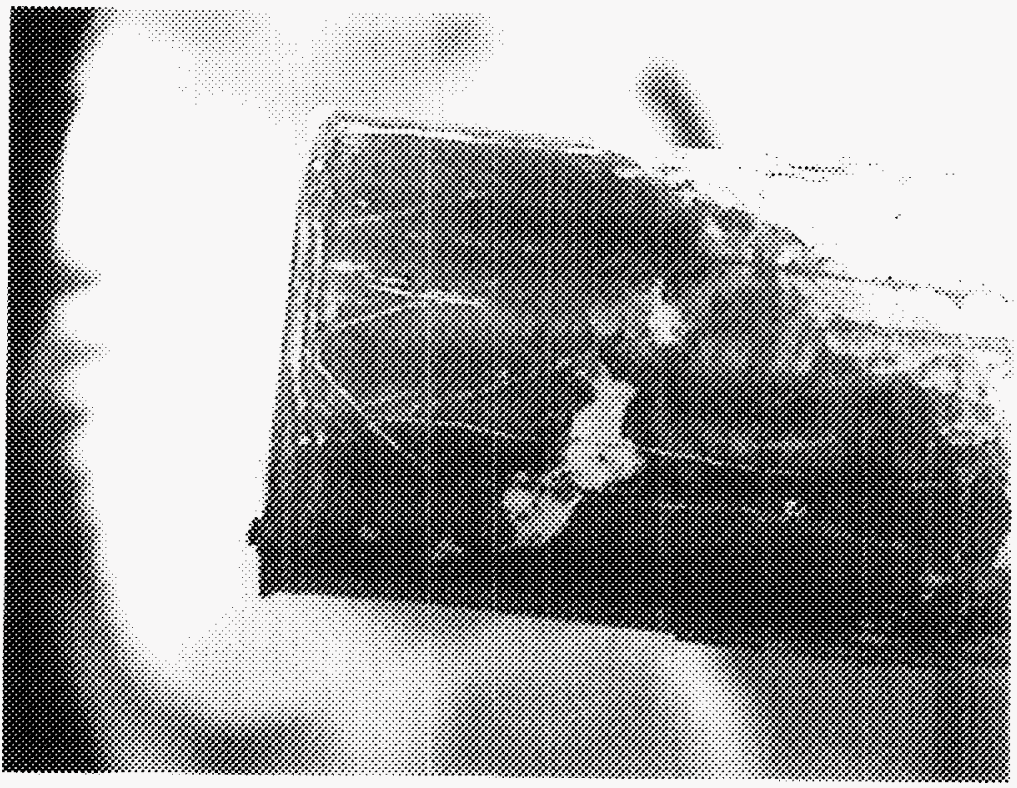




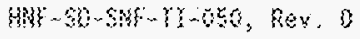

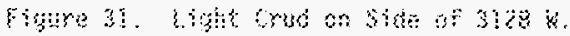

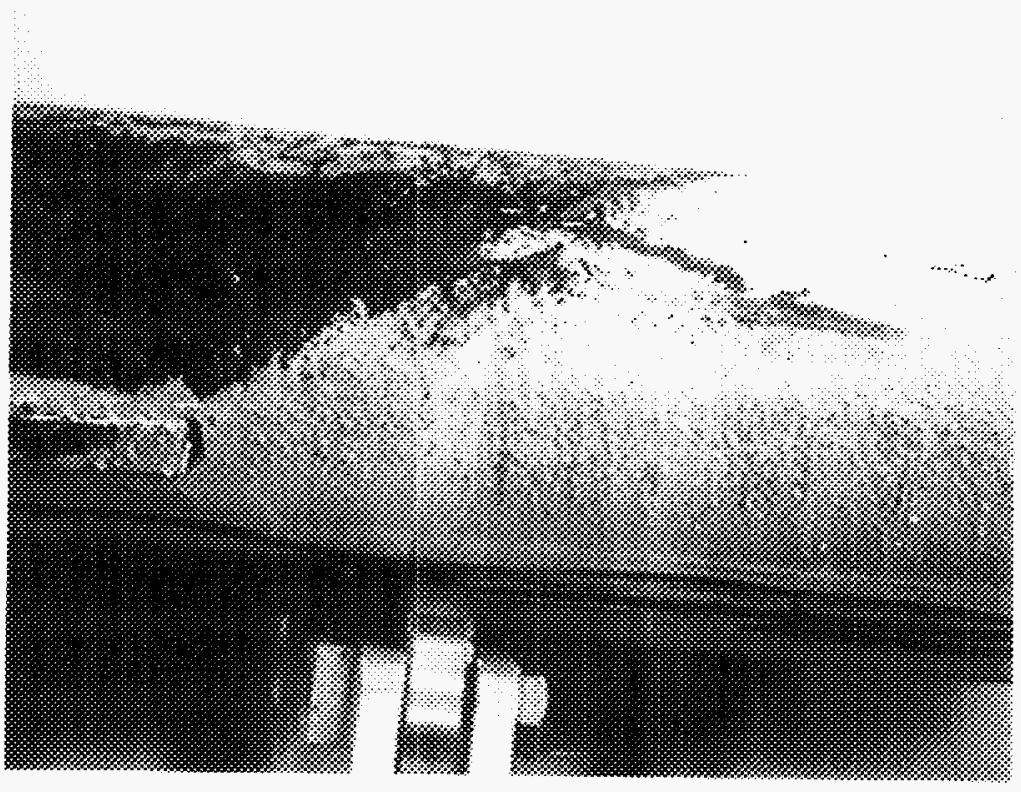




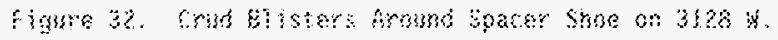

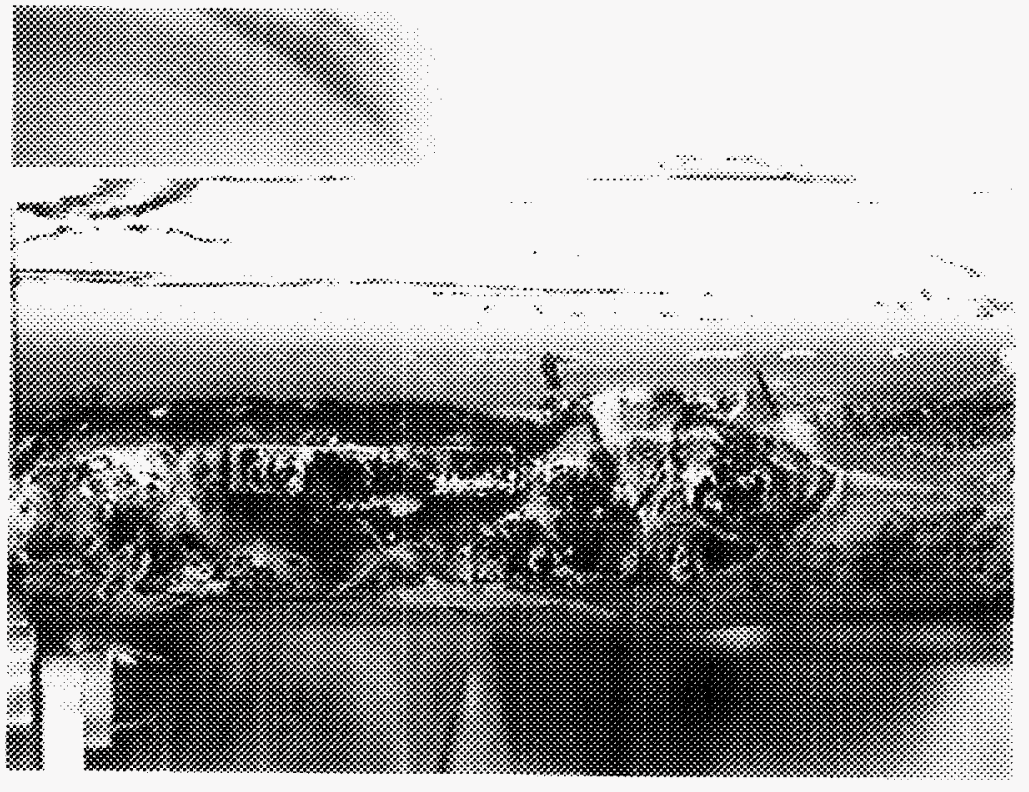




\subsection{FUEL ELEMENT 5069 E}

Photos of the in-basin sampling of the $5069 \mathrm{E}$ fuel element are shown in Figure 33. The top end was in apparently good condition, but the bottom end was flared open and sludge trailed from it as the element was handled. A small hole in the side of the cladding was also evident near the mid section of the element.

No bubbles were observed when the lid was removed from the SFEC in the hot cell. In-cell composite photos of $5069 \mathrm{E}$ are shown in Figure 34 . The highly damaged bottom end is apparent in these presentations. In making the orientation markings on the element, an inappropriate marker was used, resulting in considerable dribbling and running of the paint.

A close up of the cladding hole visible in the in-basin sampling (Figure 33 ) is shown in Figure 35 . Hot cell observations confirmed that this was a through-wall penetration. The location of the penetration was about $15 \mathrm{in.} \mathrm{down} \mathrm{from} \mathrm{the} \mathrm{top} \mathrm{at} \mathrm{the} 75^{\circ}$ orientation.

During one of the photography sessions, the fuel element was inadvertently dropped about three feet to the hot cell floor. Examination after the drop revealed no apparent additional damage, with the exception of some possible fuel loss from the open bottom end of the element. (Floor debris prevented any positive identification of fuel pieces). End views of the element before (Figure 36) and after (Figure 37) the drop indicate there may have been some small loss of fuel in the $90^{\prime}$ clock to $120^{\prime}$ clock region. If so, the amount of fuel loss appears to have been small. 


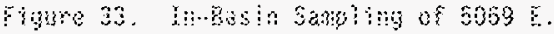

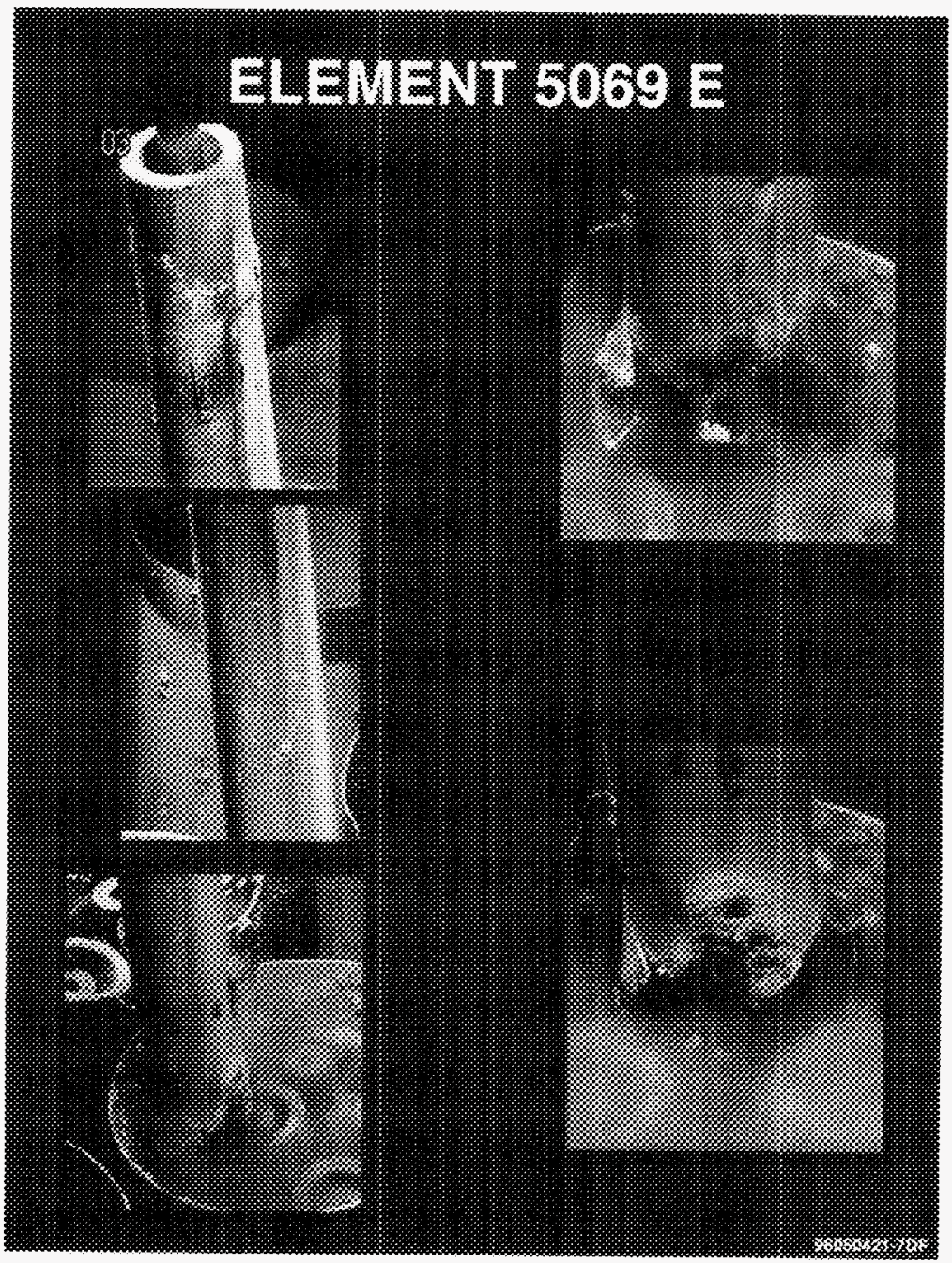




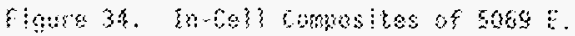

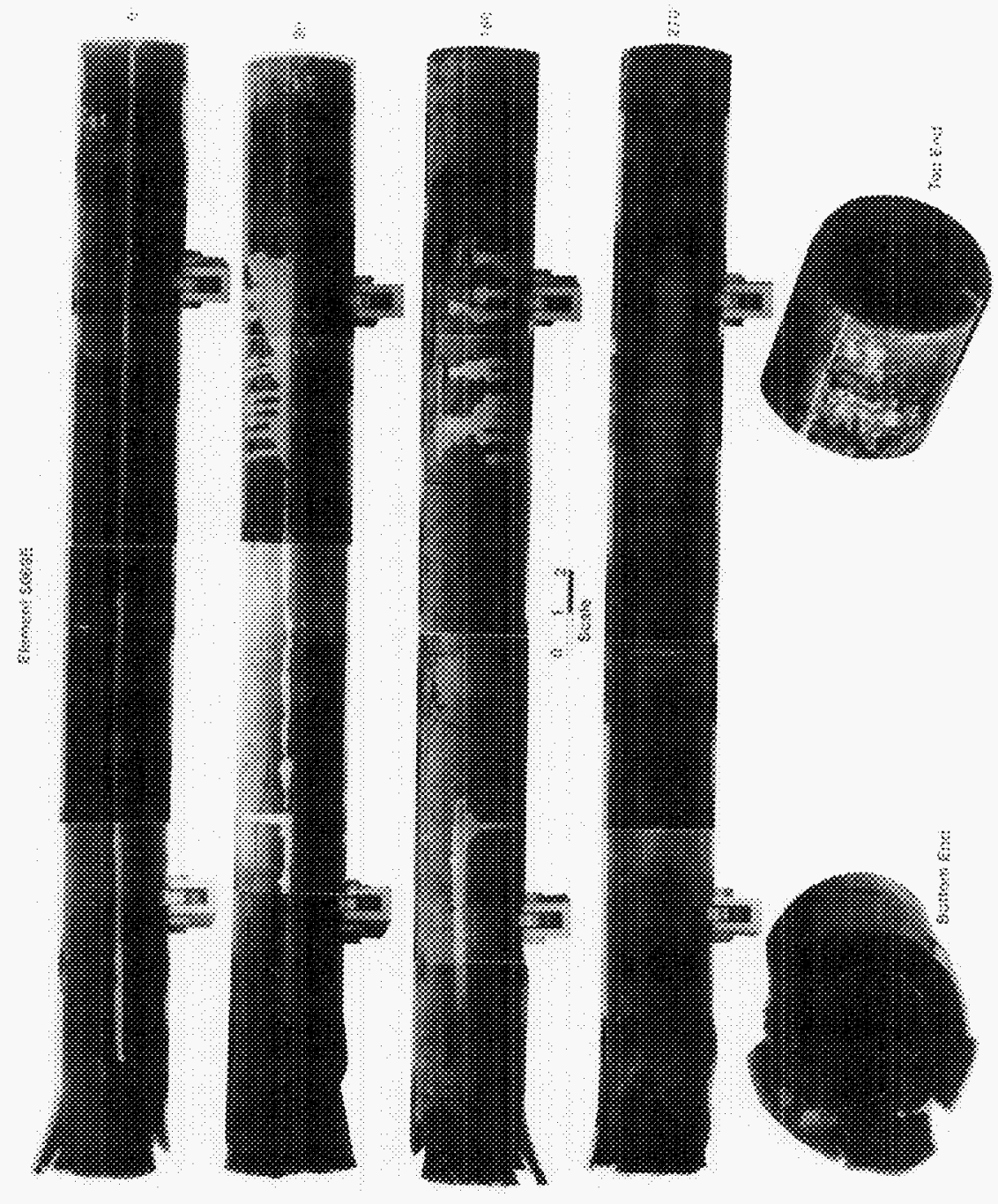




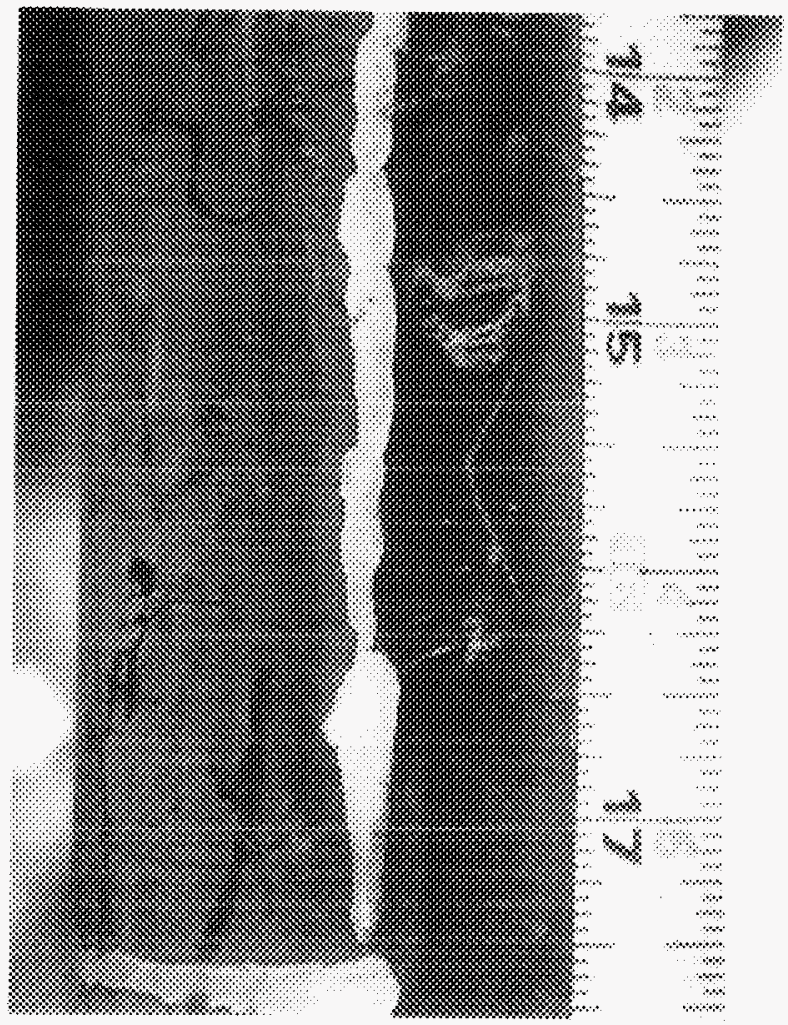

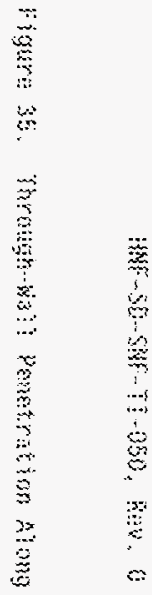

6

5

空 


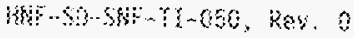

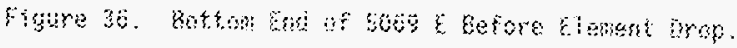

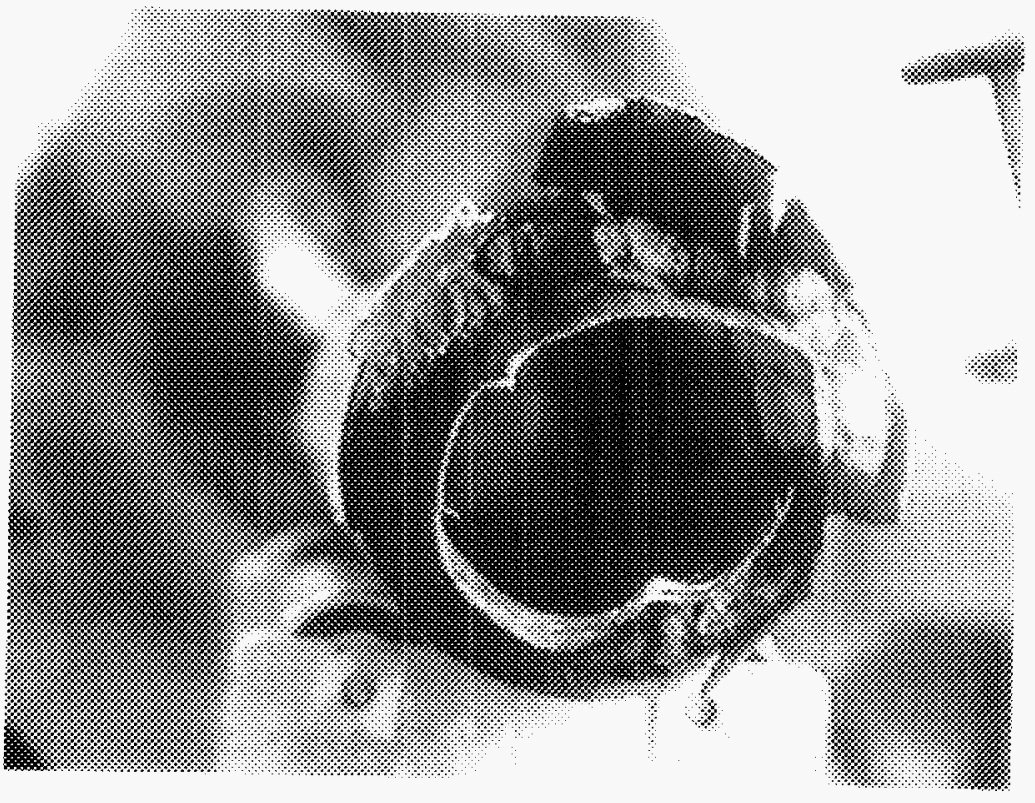




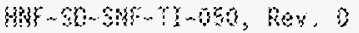

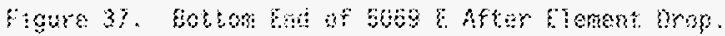

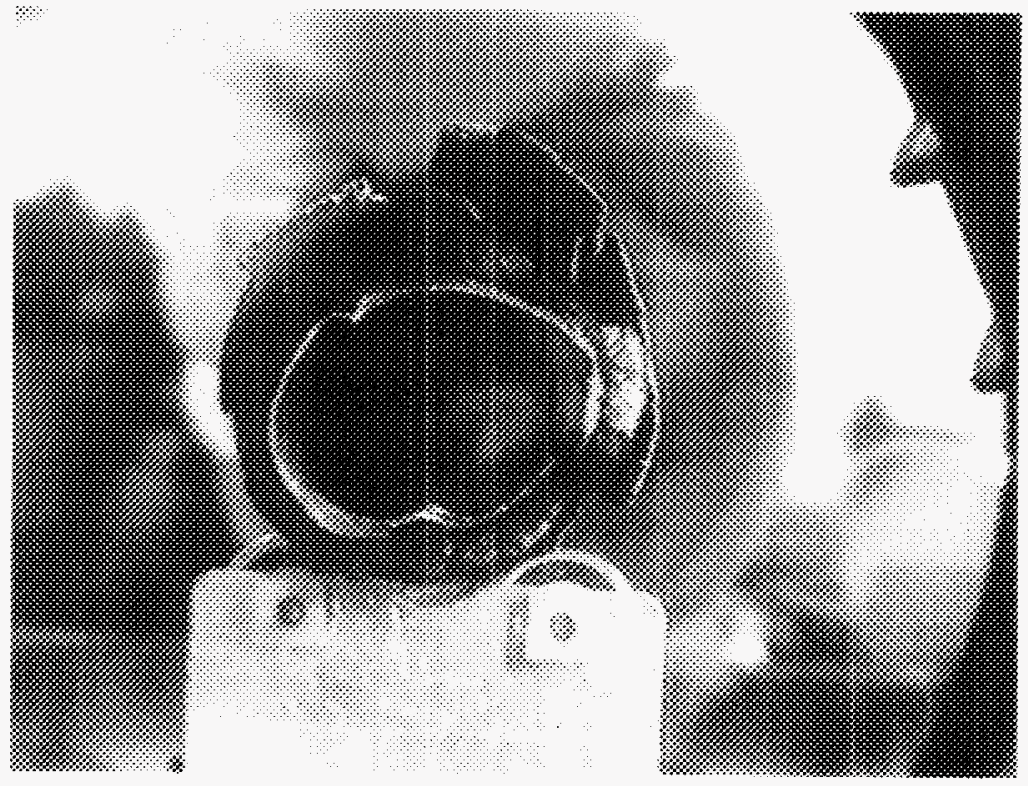




\subsection{FUEL ELENENT 5427 E}

The extraction of the $5427 \mathrm{E}$ fuel assembly from its canister in $\mathrm{K}$ East Basin is shown in Figure 38. The inner element was stuck inside the outer element, so both were transferred to the SFEC as a unit. The top end of the outer element was seen to be highly damaged, and it was apparent that the bottom end was failed as well. Some sludge exited the damaged areas during the transfer operation, but it was relatively moderate in nature. While a circumferential crack was evident near the mid-section of the outer element (Figure 39), it appeared to be still intact as it was transferred to the SFEC. Experience has shown, however, that the broken sections of outer elements sometimes match up very closely and appear to be intact when lifted by the stuck inner element, when in fact they are not. Thus, it is not known whether the outer element was actually broken into two sections when transferred to the SFEC, but it is not believed so based on videotape reviews.

No gas bubbles were noted when the SFEC 1 id was removed. When the inner element was first engaged and lifted, it again hooked the outer element after being raised about 2 in. After lowering to the bottom and 1 ifting once again, the inner element cleared the outer element and was removed from the SFEC.

Initial attempts to grapple the outer element were unsuccessful, due to the distortion of the cladding inner diameter as shown in Figure 40 . An aluminum flaring tool was fabricated to open up the inner diameter, shown in Figure 41. The inner cladding was successfully reshaped to the point where the element could be grappled and removed from the SFEC. However, the element was definitely broken at this point and was removed in two pieces. The flaring operation was quite physical, and could well have caused the element to break.

In-cel1 composite photos of the top and bottom halves of $5427 \mathrm{E}$ are shown in Figures 42 and 43 , respectively. The top and bottom ends of the element are seen to have substantial damage, particularly the top end where there is considerable split cladding and fuel voiding. However, there was some definite fuel voiding at the bottom end as we11. Additionat loose fuel particles fell from open areas of the element during handling in the hot cell.

The break area near the mid-section of $5427 \mathrm{E}$ is shown in Figures 44 and 45 for the top and bottom sections, respectively. The break appears to be relatively clean with intact fuel. The appearances of the broken surfaces seem to support the premise of a fairly recent occurrence.

In Figure 46, the top and bottom sections have been temporarily rejoined on a hanger in the hot cell. The break location is 12 to 13 in. from the bottom end of the element. While the fit-up of the two sections matches fairly well, the break itself is still plainly evident. During the in-basin transfer of the element, the cladding crack in this area had a much more closed appearance (Figure 39). Accordingly, it is believed that the break occurred during shipping or hot cell handling, quite likely during the flaring activity. 


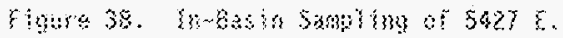

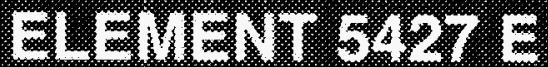
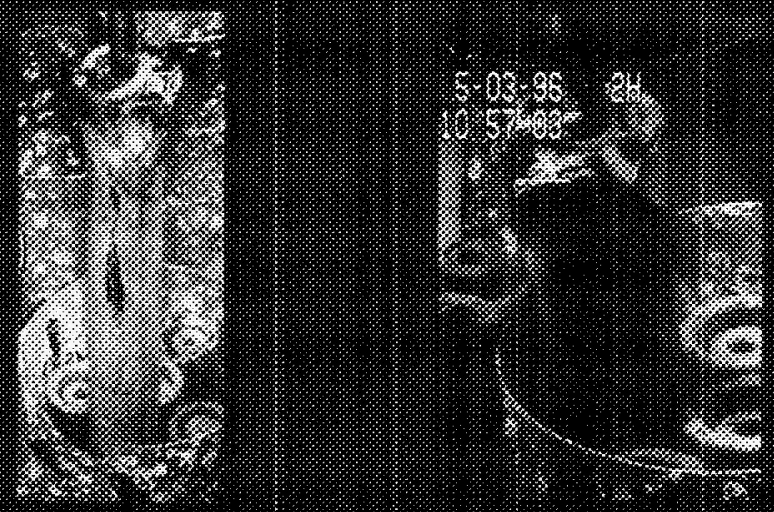
HF $-50-54-\{1-630,86 \mathrm{~V} .0$

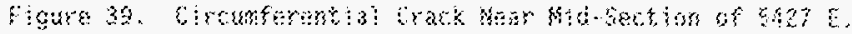

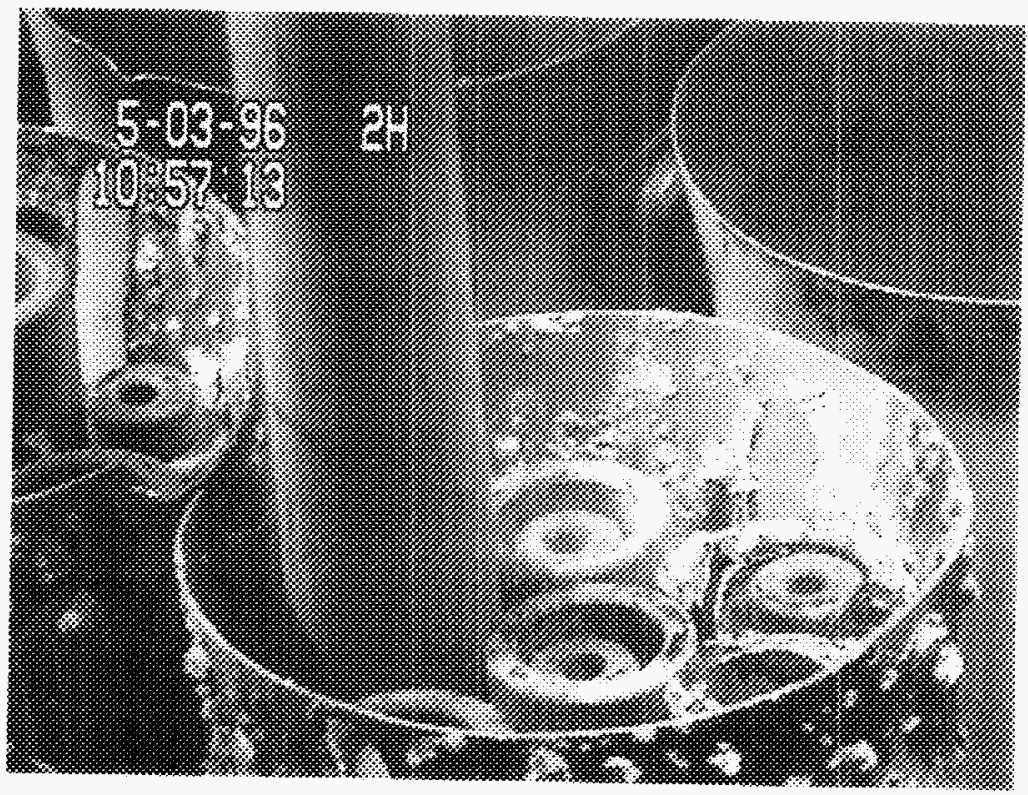




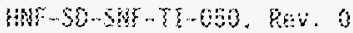

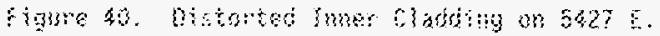

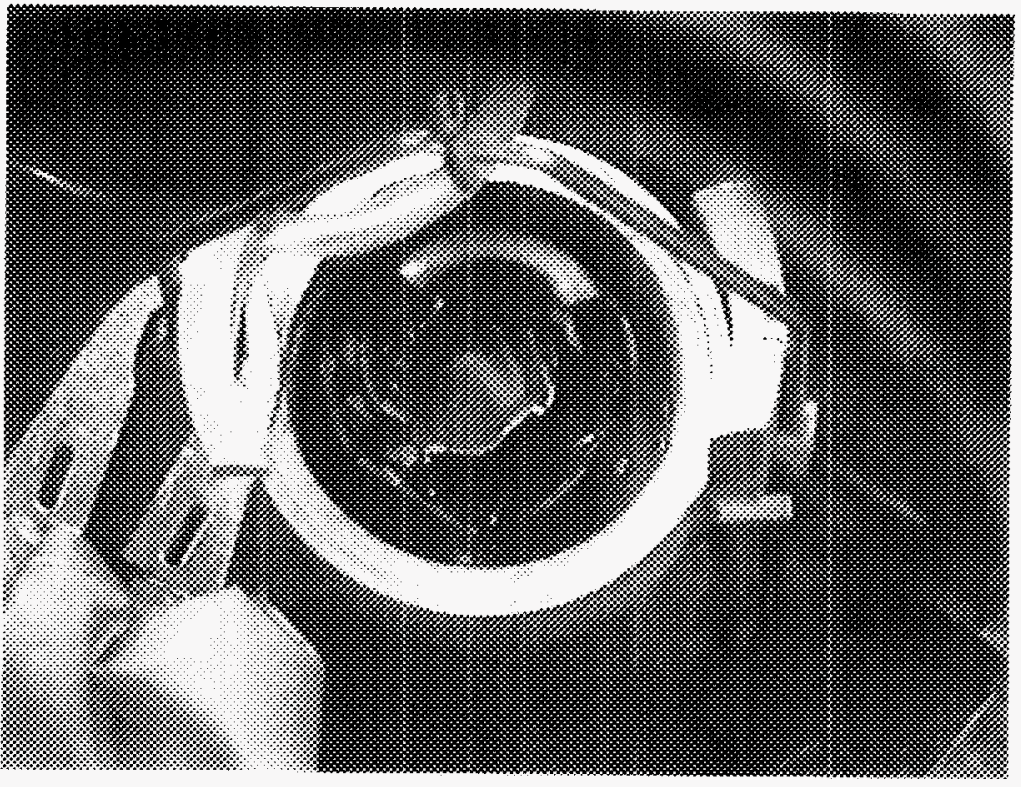




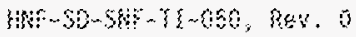

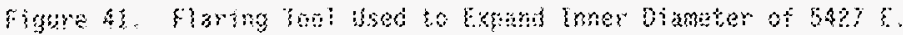

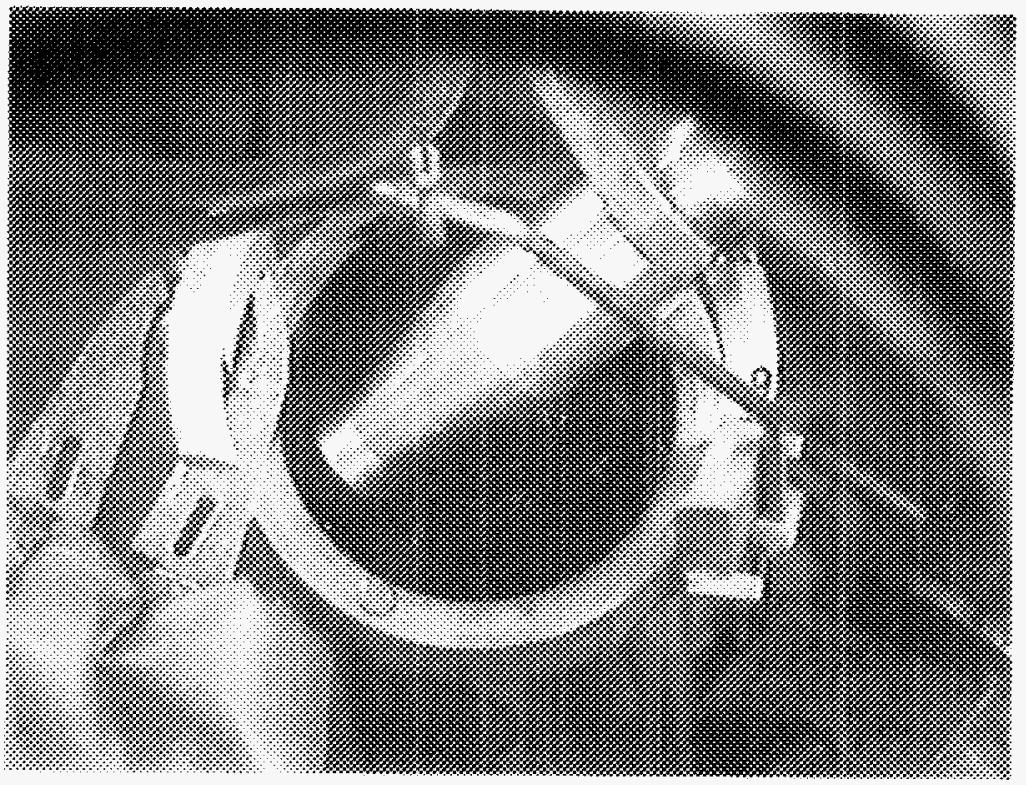


Fioure d2. In-Ce: I Comosites nf lop End of sat?

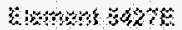

Son wsot
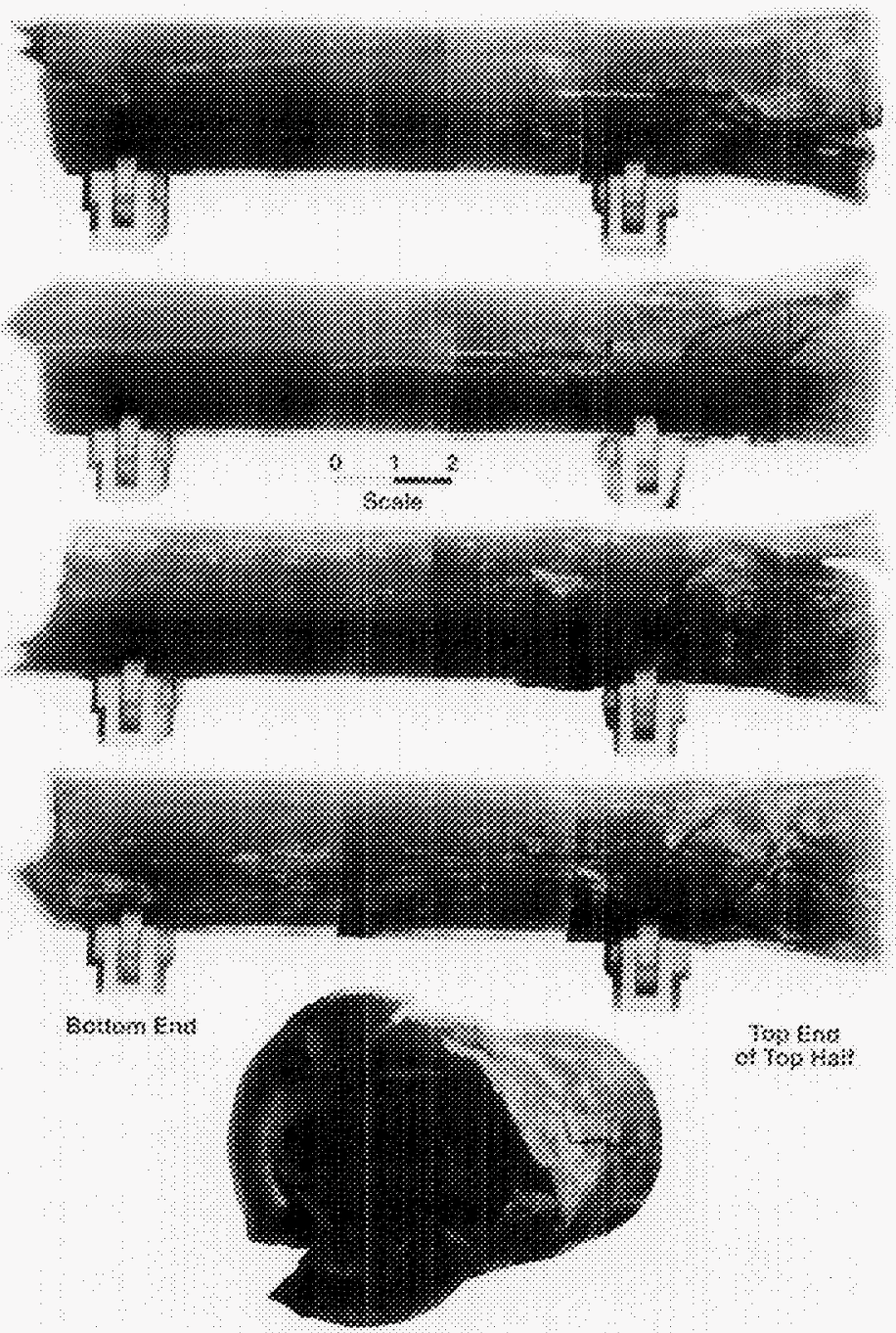


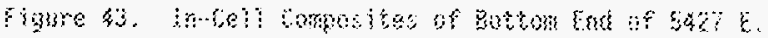

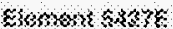 osssoss nhas}
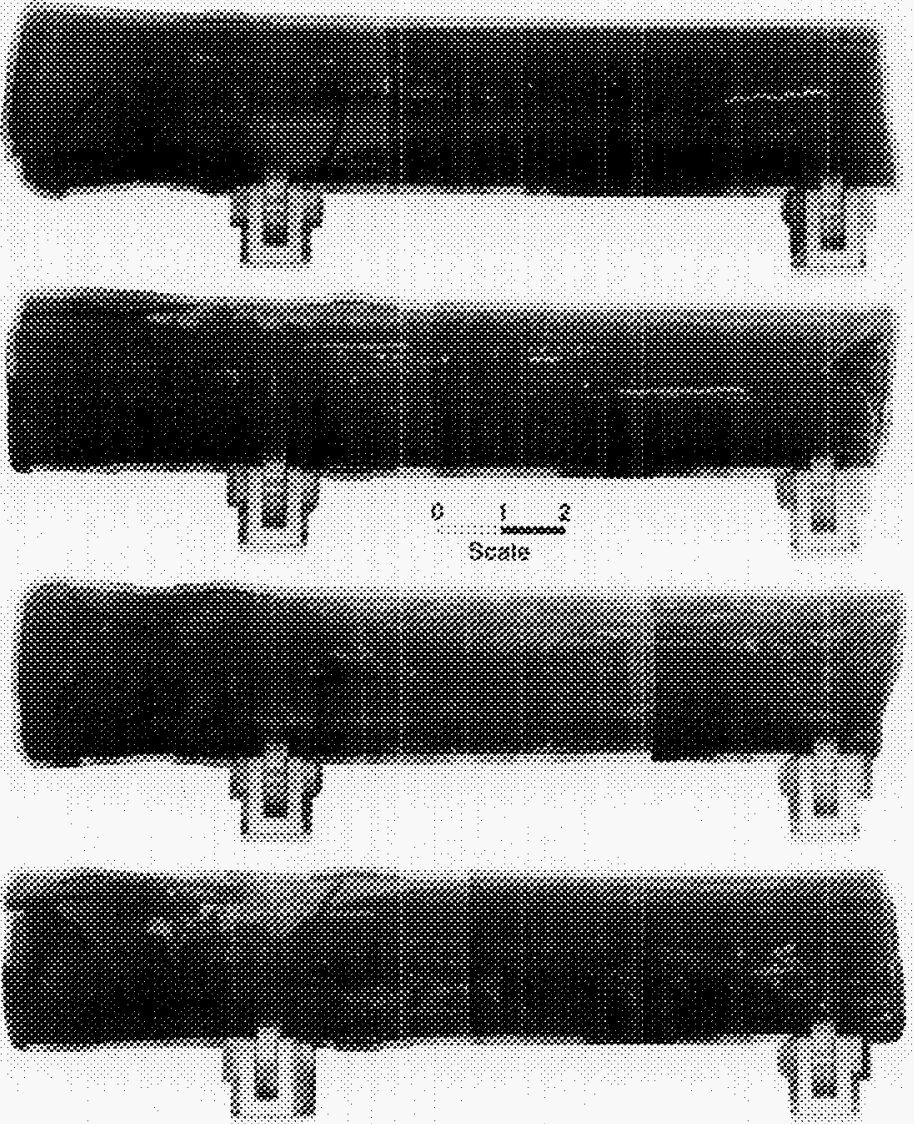

sotumber

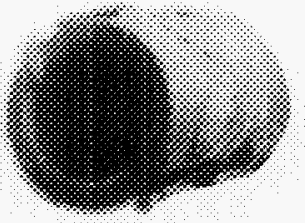




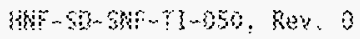

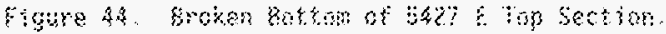

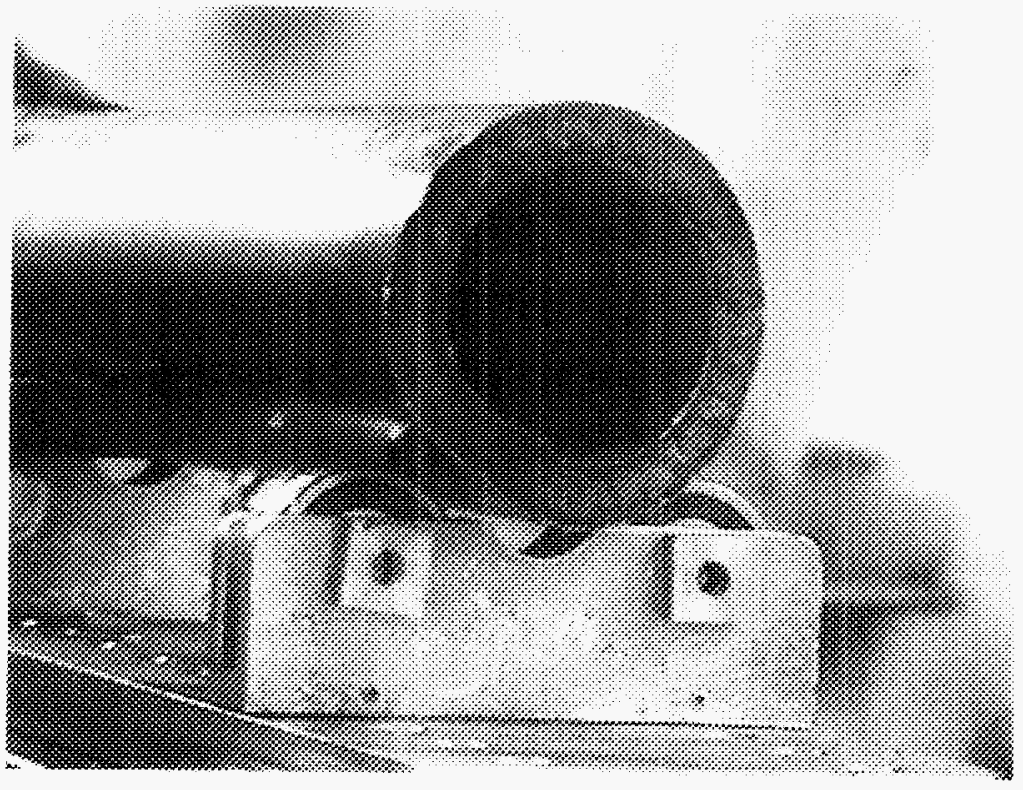




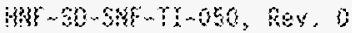

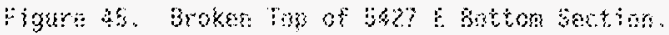

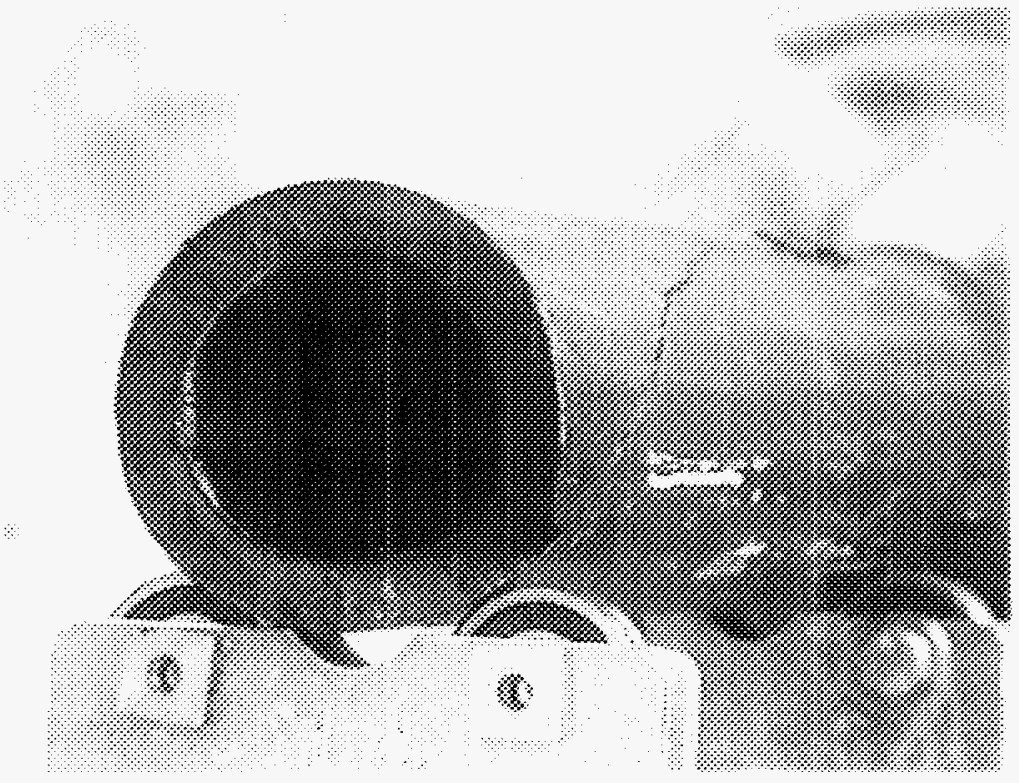




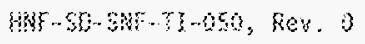

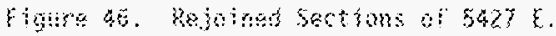

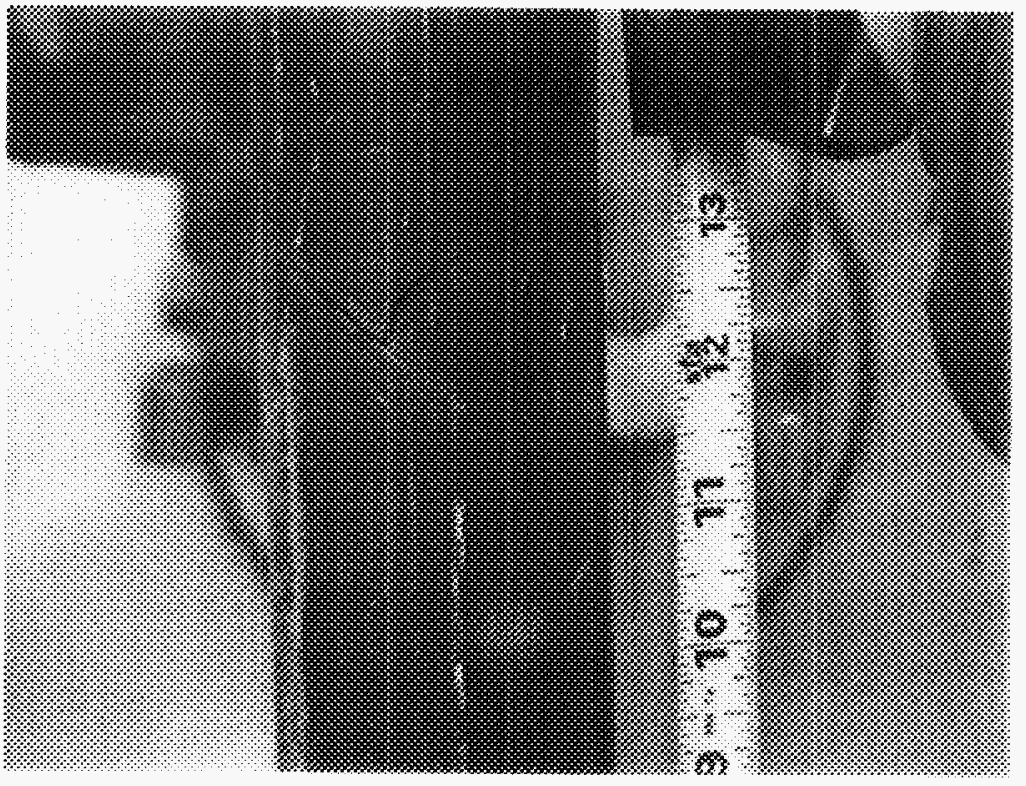




\subsection{FUEL ELEMENT $5608 \mathrm{E}$}

Figure 47 shows the extraction of $5069 \mathrm{E}$ from its canister in K East Basin. There appears to be a small breach at the top of the fuel element, and significant cracking of the cladding at the bottom of the element.

There was no bubbling observed when the lid was removed from the SFEC in the hot cell. Composite photos of the element taken in-cell are shown in Figure 48. The element had a light-colored coating on it that was easily removed, as evidenced by the numerous handling scratches seen in the composites. There was substantial cladding cracking over about the lower 4 in. of the element, and there was a break in the bottom end cap at about the $20^{\circ}$ orientation. A close up of the cracked area on the bottom end is shown in Figure 49. At this point the element had not been completely dried in the hot cell, and some wetness around the cracks is visible where captured water continued to seep out.

The suspected breach on the top end is confirmed in the close up view of Figure 50 . Separation between the cladding and end cap can be seen over about a $20^{\circ}$ arc near the bottom of the photo. 


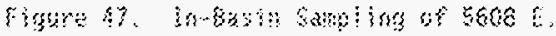

\section{ELEMENT $5608 \mathrm{E}$}
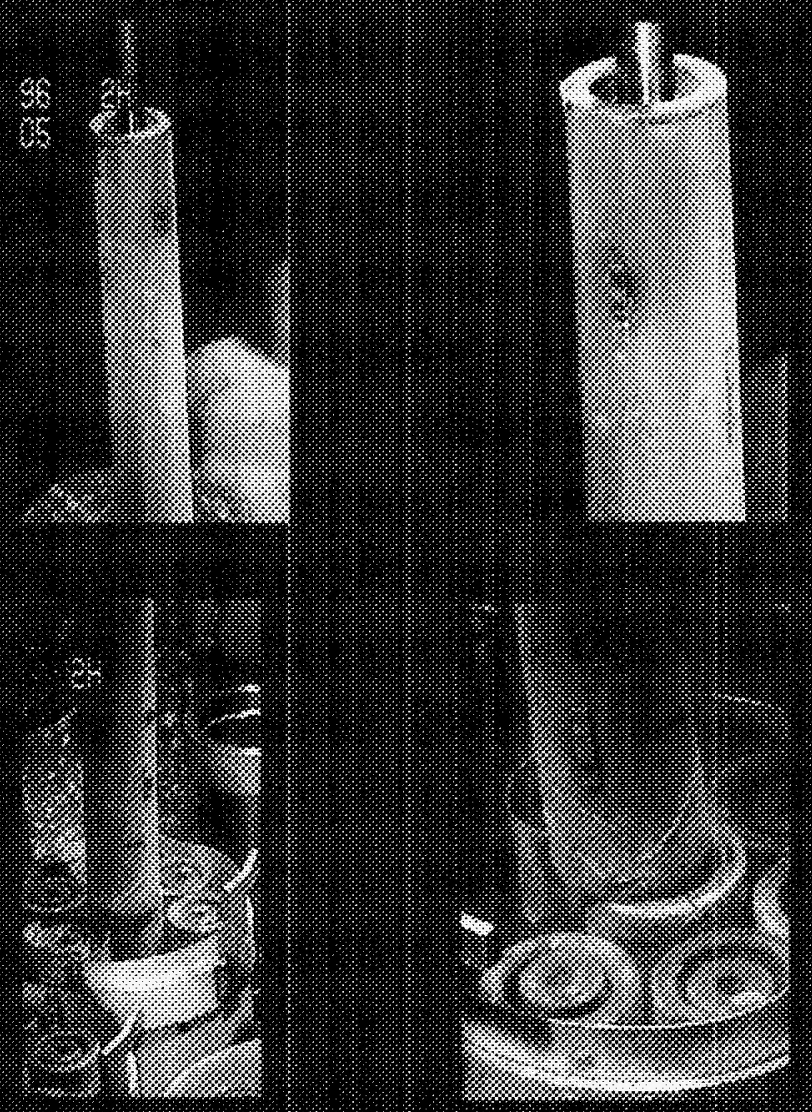


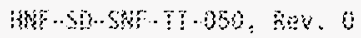

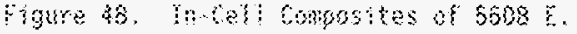

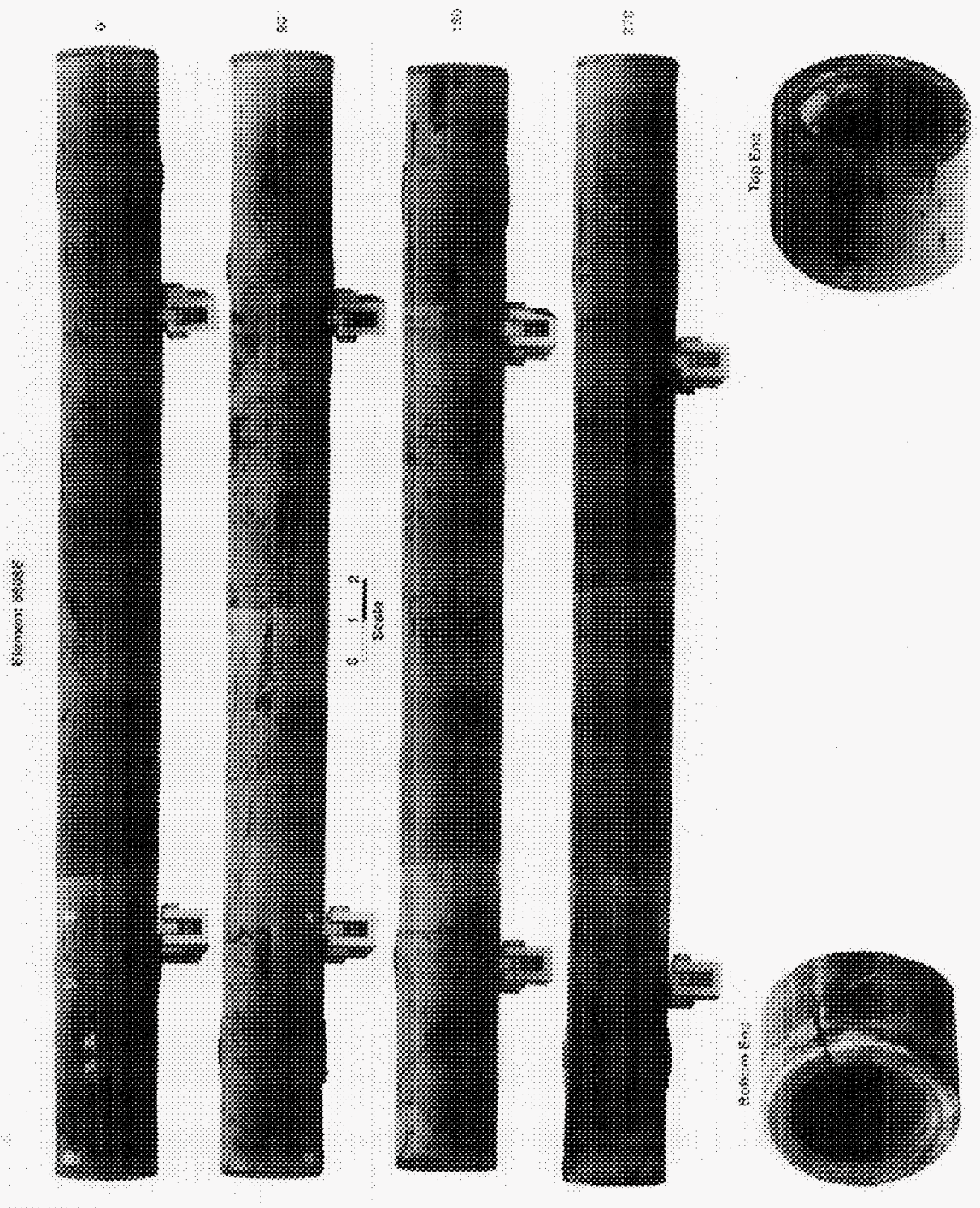




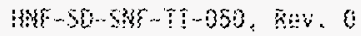

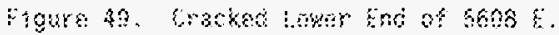

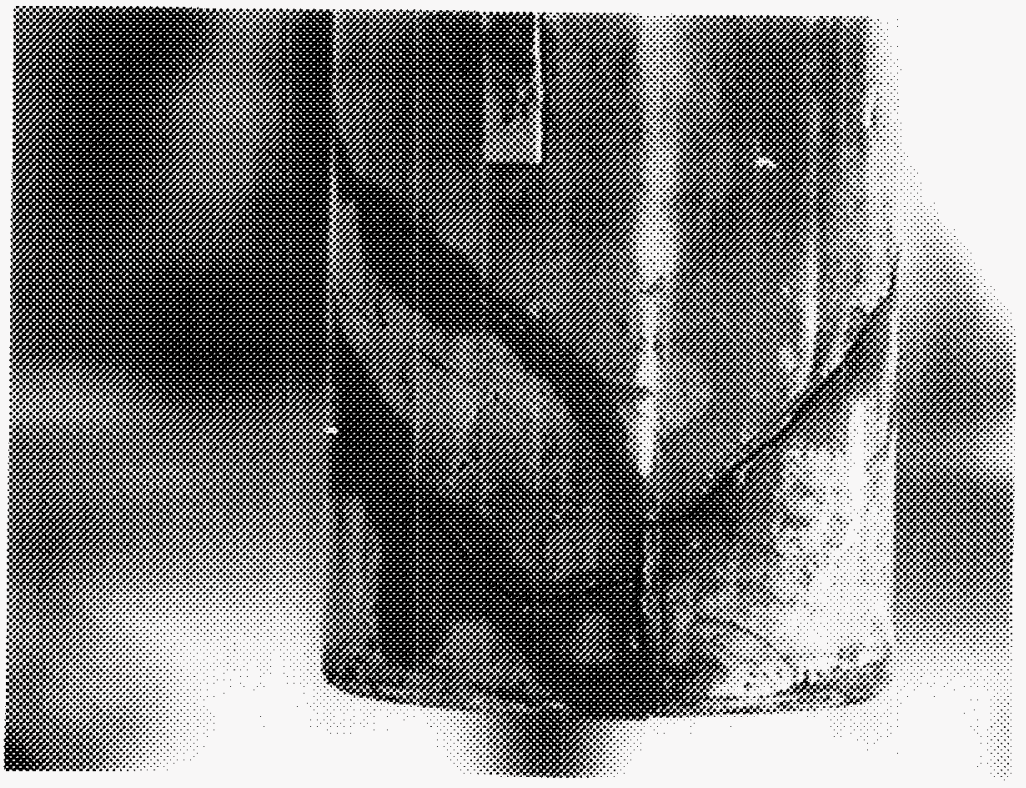




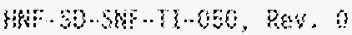

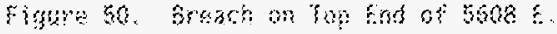

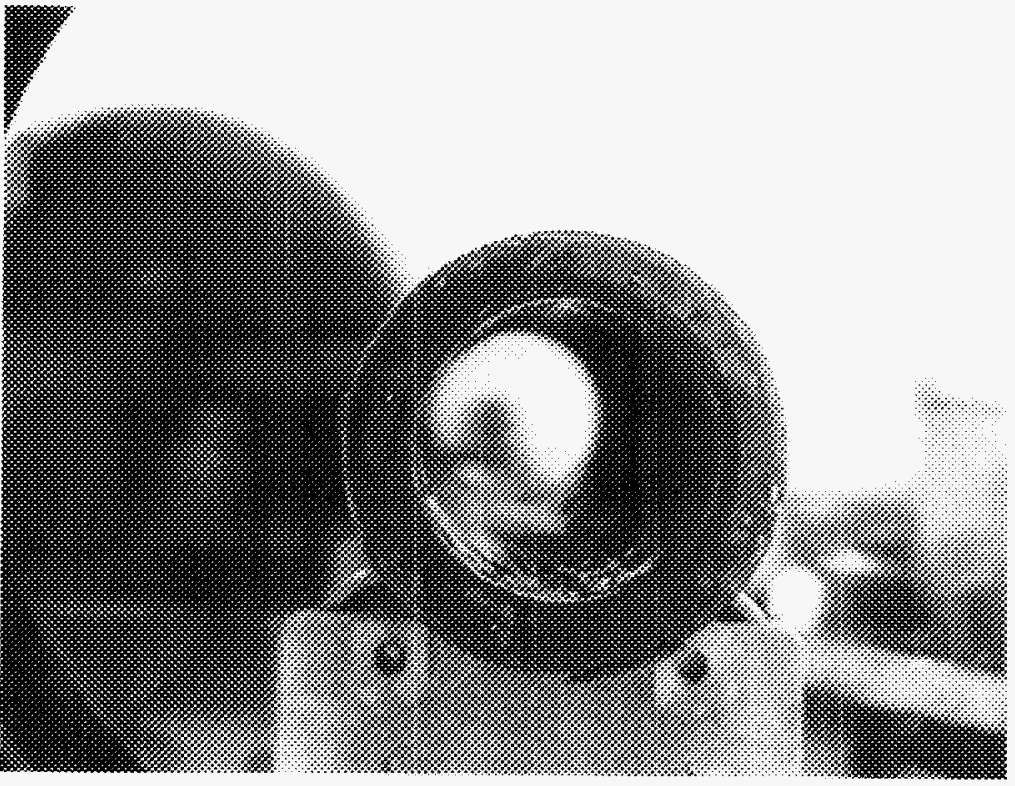




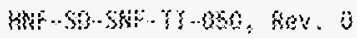

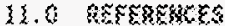

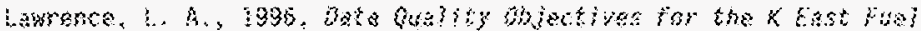

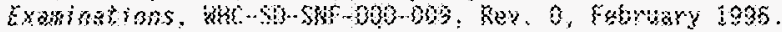

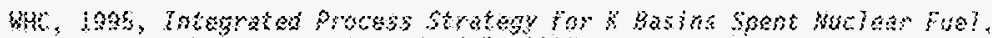

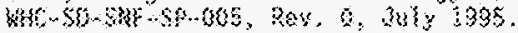




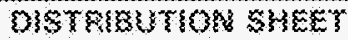

\begin{tabular}{|c|c|c|c|c|c|}
\hline \multirow{2}{*}{ Okstribution } & \multirow{2}{*}{\multicolumn{3}{|c|}{ 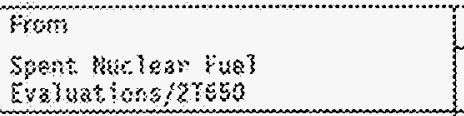 }} & \multicolumn{2}{|l|}{$\nabla_{a 3} 3$ of 2} \\
\hline & & & & \multicolumn{2}{|c|}{ 6a:a 03/03/9\} } \\
\hline \multirow{2}{*}{\multicolumn{4}{|c|}{ 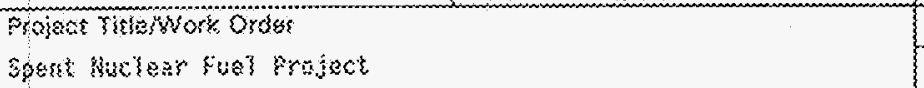 }} & \multicolumn{2}{|c|}{ ETT \& } \\
\hline & & & & \multicolumn{2}{|c|}{ ECN RSO } \\
\hline vame & $\sin$ & $\begin{array}{l}\text { Text } \\
\text { With All } \\
\text { Attuch. }\end{array}$ & rat only & $\begin{array}{l}\text { Artach } \\
\text { Apszrobix } \\
\text { Oniy }\end{array}$ & $\begin{array}{l}\text { EWTEO } \\
\text { oniy }\end{array}$ \\
\hline
\end{tabular}

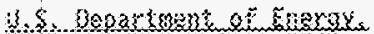

Hohland beent one of of ise

\%. E. 10stos

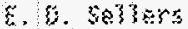

3. shuen

i. 0. Tremenas

$59-61$

$5 y+41$

$57-43$

$57-41$

$x$
$X$
$X$
$y$

g. is sroter joc.

T. L, ห̧e sh

$x-60$

Mor Donie Horifwest

h.d. Carios

9. Kumberer

5. A. Sorith

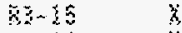

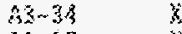

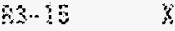

is 83 isst

O. fraston

R. $\xi$. Uen $3 \mathrm{se}$

03.5\% $x$

$63-82 \quad x$

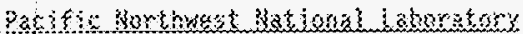

3. atrenth

A. 8. Jomson

S. C. Marsinoman

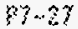

$x 8+34$

$9 \% .2 \%$

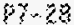

$45-46$

P. A. Seots,

然. $\%$

3. S. Shor

3xi-36 $\quad x$

Sol Curius Serves borm.

A. L. Qajuties

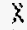

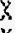

$x$

Que Engingering \& sorices finford ince

5. A. ASdemin

R. 8. Gaker

[. $\forall$. Eergmam!

k. W. Eerosmat?

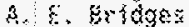

3. A, Erigs:

L. D. Erwowemars

8. A. Carlisio

5. A. Chistain

$33+88$

$40 . .48$

$83-80$

3.49

$130-40$

$139-40$

$130-80$

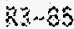

$30-30$

R. 8. Cowan

C. Jefigh grice

83.05

$83-79$

3. 8 . Gunckn

83.86

3. R. Freder iskson

Q3-s\&

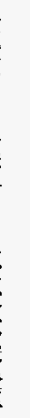


DISRBSUTON SHEET

\begin{tabular}{|c|c|c|c|c|c|}
\hline To & \multirow{2}{*}{\multicolumn{3}{|c|}{ 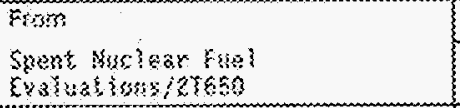 }} & \multicolumn{2}{|l|}{ Pags 2 of 2} \\
\hline Sistrigution & & & & \multicolumn{2}{|c|}{ Qhto $03 / 0367$} \\
\hline \multicolumn{4}{|l|}{ Broject Thlorkork Ondar } & \multicolumn{2}{|c|}{ 50T No. 82036$\}$} \\
\hline Snont kuchanr Fue\} Project & & & & \multicolumn{2}{|l|}{$\mathrm{ESAN}$} \\
\hline Msma & MSTN & $\begin{array}{l}\text { TEyt } \\
\text { Shith Aly } \\
\text { Risach. }\end{array}$ & Taxt Ority & $\begin{array}{l}\text { Arischi } \\
\text { seppendik } \\
\text { Osty }\end{array}$ & $\begin{array}{c}\text { EDACR } \\
\text { Ority }\end{array}$ \\
\hline
\end{tabular}

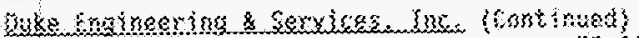

t. 4. 6robnann

S. Harkt

$\xi$ G. Husbsm

$83-66$

3. 2. Jerrbers

$30-80$

$\begin{cases}3+3 \\ 3\end{cases}$

3. 1. Кea

3. A. Lakrence

9. 6. levoy

8. i. Bskenas

R. H. $\{\operatorname{sen}\}$ \&

*. 0, SIIT

c. P. Miska

$x 3-72$

53.35

40.50

$03-35$

$80-40$

$83 . .79$

03.85

$63 \times 35$

R. $P$. vminas

$30-40$

3. 3. Foker

$23 \cdot 48$

T. R. Patily

x. 1. Pearse

$x 3.85$

Kunso

A. 1. Pisnge (10)

D. W. Rasmissen

$30-30$

25-85

X. R. Re 3$\} y$

E. j. Shen

83.80

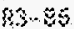

P. K. Shen

$43)-80$

D. 6. Sibuoway

3. 4. Snith

$33-32$

$83 \cdot 15$

3. A. Swensor

D. 3. Kiksus:

$\{3 \cdot\}$.

$\times 3 \cdot 35$

C. A. Ķwonson

R3-35

3. A. Trimis

$40-40$

sentral filas

or.

A. 88

$A 3-9 B$

$x$

s.

s.

$x$

$\hat{x}$

3

$\ddot{x}$

x

s

$y$

$x$

$x$

$x$

$x$

$x$

$x$

$x$

$\not{x}$

s.

\%

$x$

$x$

$x$

$x$

$x$

$x$

$\ddot{x}$

$23-1 y x$

$30-38 \quad x$

3. 3, lrwin

Bugagac Gufurs fongorat ior

O. B. Bowr I sod

F. U. Branthas

3). E. Sillo

I. A. Fimant

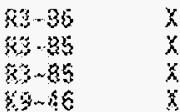




\section{SESTRXUTXOR SHEET}

\begin{tabular}{|c|c|c|c|c|c|}
\hline 73 & \multirow{2}{*}{\multicolumn{3}{|c|}{ 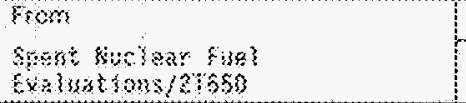 }} & \multicolumn{2}{|c|}{ Parse $Z$ of $Z$} \\
\hline Westration & & & & \multicolumn{2}{|c|}{ onte as,osis7 } \\
\hline \multirow{2}{*}{\multicolumn{4}{|c|}{ 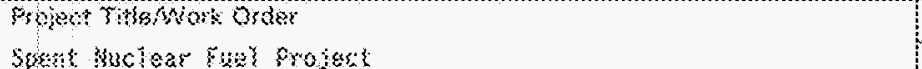 }} & \multicolumn{2}{|c|}{ EOY No. 636781 } \\
\hline & & & & \multicolumn{2}{|c|}{ gos Gs. } \\
\hline Nams & shot & $\begin{array}{l}\text { Foxt } \\
\text { Witn A3S } \\
\text { Btrack. }\end{array}$ & Taxt Oriy & $\begin{array}{l}\text { Arosoh. } \\
\text { Amondix } \\
\text { Gniy }\end{array}$ & 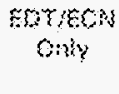 \\
\hline
\end{tabular}

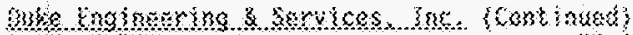

3. H. Goksmanm

S. L. Hexhs,

F. B. Buodson

3. A. 3ernbers

4. 1.08

1. A. histence

G. E. Letsy

Z. U. Makmos

3. B. Meithle

*. T. Misls

t. B. Bisha

\%. p. Bnserg

1. A. Buker

3. ค. \$3is?

x. B. Pespree

A. R. Pitater $\{10\}$

3. 12. Razkassen

N. x. $8977 \mathrm{~s}$

‥ I. Shen

צ. K. Shen

a. 1. S1000ay

3.

3. A. Sweoson

a. s. Yaksum

6. R. Thumson

3. 3. Brimbs

$203 \cdot 36$

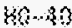

a3-313

$x 3-72$

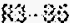

\$6. 30

$\{3 \cdot 1$

(6). 10

(3). 39

$83 \cdot 65$

$3: 3-30$

$40-33$

\$3- 33

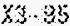

《3-30

$40-30$

$03+36$

$83 \cdot 30$

1... 56

4h.

$x 3-73$

83- 35

\{3. $\}\}$

$x 3-3 x$

$83-35$

कि...3

$43 \cdot 38$

antral fi\}as

$6 \%$

$33-34$

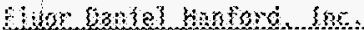

E. d. berber

k3) 3$\} \quad x$

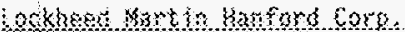

3. $\mathrm{m}$ in

$\min x$

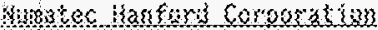

0. K. Qourlard

$33-85 \quad x$

F, B. Yradkho

23.25

\%3.

3. F. Fils

10.36

$x$
$x$
$x$
$x$ 


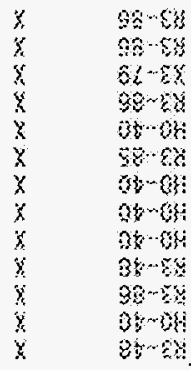

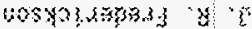
"a

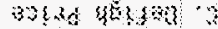
4ब

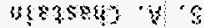
की 1303 's 8 यस

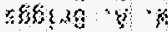
$5.80 \% 39 \cdot 3 \cdot 8$

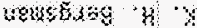
4us

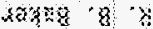
vasumb ' $\mathrm{C}$

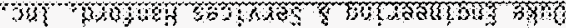

$\times \quad$ sष्ब

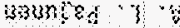

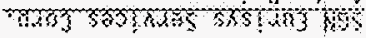

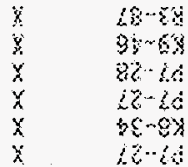

$2 x+4 \cdot 6 \cdot s$ 73005 ' 6 eyser ' $\mathrm{g}$ ': megus आosupg . 9

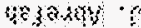
Xor

$x \quad 28+x$

$\mathrm{y} \quad 2 \mathrm{~s}$

astimo ' 8 wores Terey $\rightarrow$ I

$\begin{array}{ll}x & s[x \\ x & s \leq-0\} \\ x & s\{-8\}\end{array}$

$4305 \cdot 8$ 30k040m उसx $403 \cdot 7$

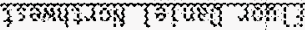

$3 \quad b ;$

$4013 \times 4+9$

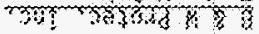

$\begin{array}{ll}x & \{y \cdot z S \\ x & 1 y-2\} \\ x & i \xi-30 \\ x & i \xi-2\}\end{array}$

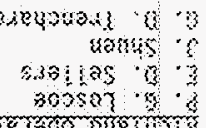

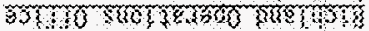

"78,

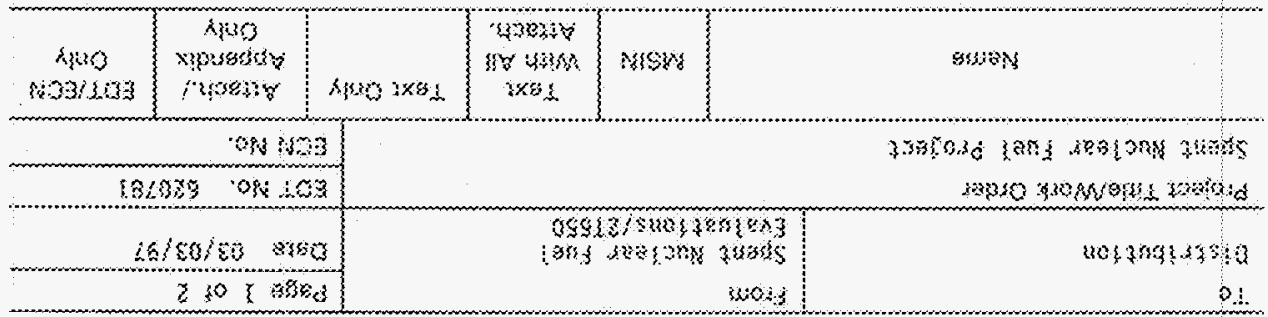

